\title{
Ultra-High Pressure Metamorphism and Geochronology of Garnet Clinopyroxenite in the Paleozoic Dunhuang Orogenic Belt, Northwestern China
}

\author{
Zhen Li ${ }^{1}$, Hao Wang ${ }^{1}$, Qian Zhang ${ }^{1}$, Meng-Yan Shi ${ }^{1}$, Jun-Sheng Lu ${ }^{2}$, Jia-Hui Liu ${ }^{1}$ and Chun-Ming Wu ${ }^{1} * * \mathbb{C}$ \\ 1 College of Earth and Planetary Sciences, University of Chinese Academy of Sciences, P.O. Box 4588, \\ Beijing 100049, China; lizhen184@mails.ucas.ac.cn (Z.L.); wanghao511@mails.ucas.ac.cn (H.W.); \\ zhangqian162@mails.ucas.ac.cn (Q.Z.); shimengyan14@mails.ucas.ac.cn (M.-Y.S.); \\ liujiahui16@mails.ucas.ac.cn (J.-H.L.) \\ 2 State Key Laboratory of Continental Dynamics, Department of Geology, Northwest University, \\ Xi'an 710069, China; lujs@nwu.edu.cn \\ * Correspondence: wucm@ucas.ac.cn; Tel.: +86-10-8825-6312
}

Citation: Li, Z.; Wang, H.; Zhang, Q.; Shi, M.-Y.; Lu, J.-S.; Liu, J.-H.; Wu, C.-M. Ultra-High Pressure Metamorphism and Geochronology of Garnet Clinopyroxenite in the Paleozoic Dunhuang Orogenic Belt, Northwestern China. Minerals 2021, 11, 117. https://doi.org/10.3390/ $\min 11020117$

Received: 27 December 2020

Accepted: 21 January 2021

Published: 24 January 2021

Publisher's Note: MDPI stays neutral with regard to jurisdictional claims in published maps and institutional affiliations.

Copyright: (c) 2021 by the authors. Licensee MDPI, Basel, Switzerland. This article is an open access article distributed under the terms and conditions of the Creative Commons Attribution (CC BY) license (https:// creativecommons.org/licenses/by/ $4.0 /)$.
Abstract: Ultra-high pressure (UHP) metamorphism is recorded by garnet clinopyroxenite enclaves enclosed in an undeformed, unmetamorphosed granitic pluton, northeastern Paleozoic Dunhuang orogenic belt, northwestern China. The protoliths of the garnet clinopyroxenite might be basic or ultrabasic volcanic rocks. Three to four stages of metamorphic mineral assemblages have been found in the garnet clinopyroxenite, and clockwise metamorphic pressure-temperature $(P-T)$ paths were retrieved, indicative of metamorphism in a subduction environment. Peak metamorphic $P_{-}$ $T$ conditions (790-920 ${ }^{\circ} \mathrm{C} / 28-41 \mathrm{kbar}$ ) of garnet clinopyroxenite suggest they experienced UHP metamorphism in the coesite- or diamond-stability field. The UHP metamorphic event is also confirmed by the occurrence of high-Al titanite enclosed in the garnet, along with at least three groups of aligned rutile lamellae exsolved from the garnet. Secondary ion mass spectrometry (SIMS) $\mathrm{U}-\mathrm{Pb}$ dating of metamorphic titanite indicates that the post-peak, subsequent tectonic exhumation of the UHP rocks occurred in the Devonian period ( 389-370 Ma). These data suggest that part of the Paleozoic Dunhuang orogenic belt experienced UHP metamorphism, and diverse metamorphic facies series prevailed in this Paleozoic orogen. It can be further inferred that most of the UHP rocks in this orogen remain buried.

Keywords: Dunhuang Orogenic Belt; garnet clinopyroxenite; geochronology; high-Al titanite; rutile lamellae; $P$-T path; ultra-high pressure metamorphism

\section{Introduction}

It is well known that the ultra-high pressure (UHP) metamorphism is anticipated to be formed during subduction at very low thermal gradient, usually less than $10^{\circ} \mathrm{C} / \mathrm{km}$, or even as low as $\sim 5^{\circ} \mathrm{C} / \mathrm{km}$, which refers to metamorphic pressure high enough to stabilize coesite [1,2]. Together with coesite, other diagnostic minerals such as coesite, diamond [3,4], Na-Ti-P-bearing garnet [5], or pseudomorph of stishovite [6,7] also certify UHP metamorphism, which usually requires ultra-deep subduction and subsequent rapid exhumation. However, these diagnostic minerals do not appear in some orogenic belts, which in turn brings people some doubts if such orogenic belts experienced UHP metamorphism.

The Dunhuang area has long been considered as an ancient stable block formed in the Precambrian $[8,9]$. Until recently, clockwise metamorphic pressure-temperature $(P-T)$ paths of eclogite, mafic granulite, amphibolite, and metapelite, typical metamorphic products of subduction setting, were retrieved elsewhere in this region [9-19], and the metamorphic event was dated to occur from Silurian to Devonian periods [10,11,14-19]. These enabled people to believe that this area was a Paleozoic orogenic belt [13,15-19]. Eclogite [15] and high-pressure (HP) mafic granulite $[10,11,14-16,18,19]$ have been found in this orogen, but 
UHP rocks have not been discovered before, which in turn limits our understanding of the orogenic process as a whole. The recognition of UHP metamorphism is challenging because the presence of minerals formed under such conditions in some orogenic belts is possible but requires appropriate physical-chemical conditions for their formation and preservation and a mechanism(s) for their exhumation.

In this contribution, we present a comprehensive study of field investigation, petrology, geothermobarometric computation, and secondary ion mass spectrometry (SIMS) U-Pb dating of titanite for garnet clinopyroxenite in the Daquan area, northeastern Dunhuang orogenic belt, to obtain their $P$-T paths and certify UHP metamorphism in this Paleozoic orogenic belt.

\section{Regional Geology}

The Dunhuang orogenic belt strikes WSW-ENE and covers an area of approximately $440 \mathrm{~km}$ long and $100 \mathrm{~km}$ wide (Figure $1 \mathrm{~A}, \mathrm{~B}$ ). It is tectonically bordered by the Paleozoic Beishan orogenic belt to the north, the Precambrian Tarim Craton to the west, the Precambrian Alexa Block to the east, and the Paleozoic Altyn Tagh-Qilian orogenic belt to the south [20] (Figure 1A). The Dunhuang orogenic belt was dismembered by sinistral strike-slip faults to several tectonic blocks [20,21] (Figure 1B), possibly in the late Cenozoic [22]. The prominent characteristics of the Dunhuang orogenic belt are that at least in the Hongliuxia, Qingshigou, Kalatashitage, and Mogutai-Dongbatu tectonic blocks, eclogite, high- and medium-pressure mafic granulite, and amphibolite occur as rootless tectonic lenses or puddings enclosed within the metapelite and metasandstone matrix [14,15,17-19], indicative of typical block-in-matrix features of tectonic mélanges [23]. Some closely amalgamated tectono-metamorphic slices can also be found in the northwestern Dunhuang orogenic belt, which were metamorphosed at different depths and were later juxtaposed in the same crustal level during tectonic exhumation [19].

Recently, we found high-Al titanite-bearing garnet clinopyroxenite and obtained UHP $P-T$ conditions of such rocks in the Daquan area, northeastern Dunhuang orogenic belt (Figure 1C). Garnet clinopyroxenite occurs as enclaves enclosed in an undeformed, unmetamorphosed granitic body, or as enclaves within paragneiss, which themselves are also enclosed in the granitic body (Figure 1D). The boundary between these metamorphic rocks and the host granitic body is clear and sharp (Figure 1D-F). However, the crystallization age of the granitic body cannot be determined due to severe decrystallization of magmatic zircon of this granitic body caused by radioactive damage. 


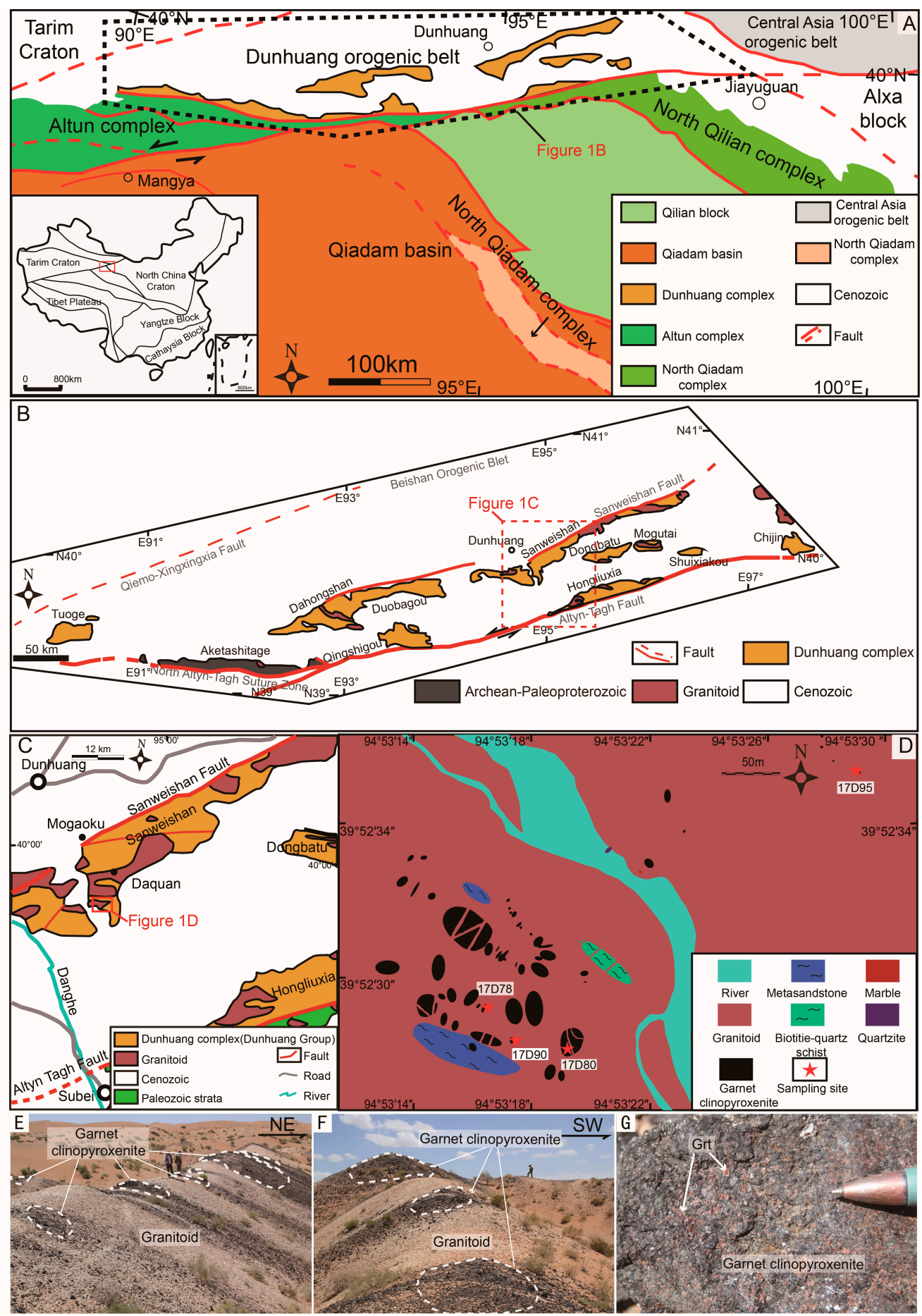

Figure 1. (A) Tectonic sketch of the Dunhuang orogenic belt and its surrounding tectonic units (modified after Zhang et al. [20]). (B) Tectonic sketch of the Dunhuang orogenic belt (modified after Zhang et al. [20] and Lu et al. [21]). (C) Geological map of the Sanweishan area (modified after 1:1,000,000 geological map of Gansu Province). (D) Geological map of the study area (based on our fieldwork). (E,F) Field images of the garnet clinopyroxenite puddings enclosed in the granitic body. (G) Hand specimen of garnet clinopyroxenite with garnet porphyroblasts. 


\section{Petrography}

In this study, we target garnet clinopyroxinte puddings enclosed in the granitoids (Figure 1D). Retrograde symplectite rimming the embayed, relict garnet of the garnet clinopyroxenite can be easily seen in the outcrop (Figure 1G). Micropetrographic features of the garnet clinopyroxenite are depicted in Figures 2 and 3. Three to four stages of metamorphic mineral assemblages were found in the four representative samples. The mineral abbreviations are from Whitney and Evans [24], and the subscripts of the minerals $1,2,3$, and 4 refer to the corresponding minerals formed at the sequential four metamorphic stages, respectively, throughout this paper.

All four samples are mainly bimineralic, consisting of garnet and clinopyroxene. The prograde assemblage (M1) is represented by the fine-grained ilmenite $\left(\mathrm{Ilm}_{1}\right)+$ plagioclase $\left(\mathrm{Pl}_{1}\right) \pm$ hornblende $\left(\mathrm{Hbl}_{1}\right) \pm$ clinopyroxene $\left(\mathrm{Cpx}_{1}\right) \pm$ rutile $\left(\mathrm{Rt}_{1}\right)$ inclusions enclosed in the garnet $\left(\mathrm{Grt}_{2}\right)$ (Figure 2A-D). High-Al titanite $\left(\mathrm{Ttn}_{2}\right)$ also appears as inclusion within garnet (Figure 2E andFigure 3A,B). The peak metamorphic assemblage (M2) consists of garnet $\left(\mathrm{Grt}_{2}\right)$ and clinopyroxene $\left(\mathrm{Cpx}_{2}\right)$, plus matrix minerals including minor rutile $\left(\mathrm{Rt}_{2}\right)$, high-Al titanite $\left(\mathrm{Ttn}_{2}\right)$, and apatite $\left(\mathrm{Ap}_{2}\right)$. The matrix rutile $\left(\mathrm{Rt}_{2}\right)$ is rare and was severely retrograded to ilmenite (Figure $2 \mathrm{~F}, \mathrm{G}$ ). The retrograde assemblage (M3) is mainly the worm-like symplectite, consisting of fine-grained plagioclase $\left(\mathrm{Pl}_{3}\right)$, hornblende $\left(\mathrm{Hbl}_{3}\right)$, and ilmenite $\left(\mathrm{Ilm}_{3}\right)$ intergrowth, rimming the garnet (Figure 2A,C,H). Similar decomposition textures in mafic granulite can be found elsewhere in this orogen and are repeatedly demonstrated to be formed by nearly isothermal decompression (ITD) during tectonic exhumation [14-16,18,19]. Other retrograde assemblages (M3) include fine-grained ilmenite $\left(\mathrm{Ilm}_{3}\right) \pm$ plagioclase $\left(\mathrm{Pl}_{3}\right) \pm$ hornblende $\left(\mathrm{Hbl}_{3}\right) \pm$ titanite $\left(\mathrm{Ttn}_{3}\right)$ lamellae exsolved from within the clinopyroxene $\left(\mathrm{Cpx}_{2}\right)$ (Figure $\left.2 \mathrm{I}, \mathrm{J}\right)$, hornblende $\left(\mathrm{Hbl}_{3}\right)$ retrograded from clinopyroxene $\left(\mathrm{Cpx}_{2}\right)$ (Figure $\left.2 \mathrm{~K}\right)$, ilmenite $\left(\mathrm{Ilm}_{3}\right)$ retrograded from rutile $\left(\mathrm{Rt}_{2}\right)$ (Figure $\left.2 \mathrm{~F}, \mathrm{G}\right)$, ilmenite $\left(\mathrm{Ilm}_{3}\right)$ retrograded from high-Al titanite $\left(\mathrm{Ttn}_{2}\right)$ (Figure 3B), and ilmenite $\left(\mathrm{Ilm}_{3}\right)$ + hornblende $\left(\mathrm{Hbl}_{3}\right)$ symplectite formed from an unknown precursor (might be high-Al titanite or rutile, Figure $2 \mathrm{~L}$ ), as well as aligned rutile lamellae $\left(\mathrm{Rt}_{3}\right)$ exsolved from within the garnet in three different directions (Figure 3C,D). Occasionally, the final retrograde assemblage (M4) can be found, i.e., actinolite $\left(\mathrm{Act}_{4}\right)$ and chlorite $\left(\mathrm{Chl}_{4}\right)$ retrograded from hornblende $\left(\mathrm{Hbl}_{3}\right)$ (Figure $\left.2 \mathrm{H}\right)$. In sample 17D95, minor spinel $\left(\mathrm{Spl}_{3}\right)$ can be found, and it mainly coexists with tremolite $\left(\mathrm{Tr}_{3}\right) \pm$ rutile $\left(\mathrm{Rt}_{3}\right)$ as idiomorphic retrograded phases within the garnet (Figure 3E). It was possibly exsolved from within garnet, similar to the clinopyroxene exsolved from within the garnet in eclogite from Sulu orogenic belt, eastern China [5]. Such inclusion-like minerals were in fact decomposed from garnet [25]. In sample 17D80, there is idiomorphic hexagon ilmenite $\left(\mathrm{Ilm}_{3}\right)$ in garnet and is separated by high-Al titanite $\left(\mathrm{Ttn}_{2}\right)$ from centerline (Figure $\left.3 \mathrm{~F}\right)$. Such reaction textures are similar to those in granulite facies metapelite and may represent extremely high- $P$ or high- $T$ conditions [26]. 

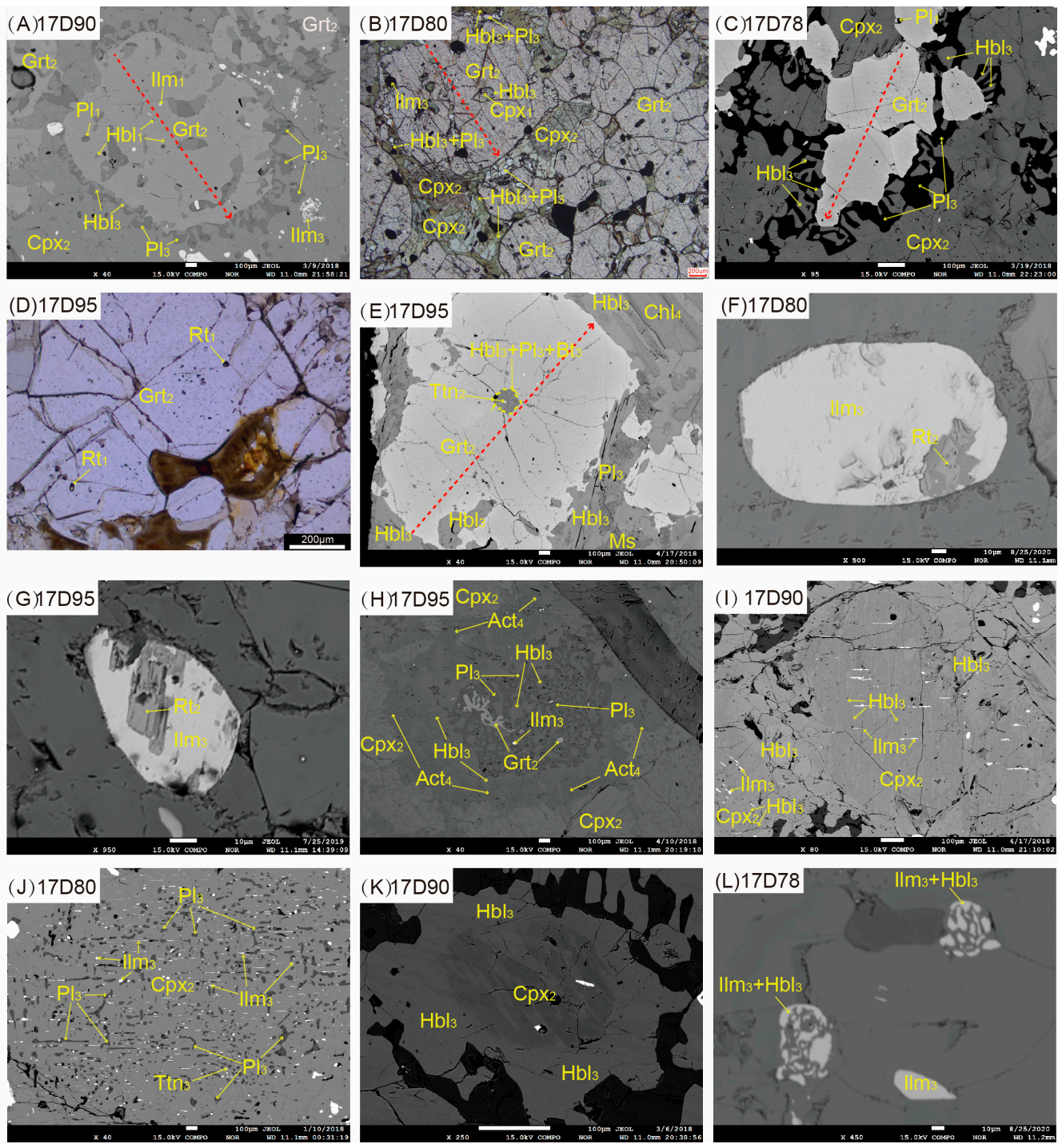

Figure 2. Micropetrography of the garnet clinopyroxenite. Subscripts 1, 2, 3, and 4 refer to the prograde (M1), metamorphic peak (M2), first retrograde (M3), and final retrograde (M4) minerals, respectively. The dashed red arrow refers to the electron microprobe analytical profile of garnet. Mineral abbreviations are after Whitney and Evans [24]. (A) The prograde assemblage (M1) is the tiny inclusions $\mathrm{Pl}_{1}+\mathrm{Hbl}_{1}+\mathrm{Ilm}_{1}$ preserved in the garnet interior. The peak metamorphic assemblage (M2) consists of $\mathrm{Grt}_{2}+\mathrm{Cpx}_{2}$. The first retrograde assemblage (M3) is the symplectic $\mathrm{Hbl}_{3}+\mathrm{Pl}_{3}$ intergrowth formed in between the matrix $\mathrm{Grt}_{2}$ and $\mathrm{Cpx}_{2}$. (B) Besides the M1, M2, and M3 assemblages similar to that in (A), the $\mathrm{Cpx}_{2}$ rim partially retrograded to $\mathrm{Hbl}_{3}$. (C) The symplectic assemblage (M3) $\mathrm{Hbl}_{3}+$ $\mathrm{Pl}_{3}$ formed between the matrix $\mathrm{Grt}_{2}$ and $\mathrm{Cpx}_{2}$. (D) Rutile ( $\left(\mathrm{Rt}_{1}\right)$ inclusions enclosed in garnet $\left(\mathrm{Grt}_{2}\right)$. (E) The retrograde assemblage (M3) $\mathrm{Hbl}_{3}+\mathrm{Pl}_{3}+\mathrm{Bt}_{3}$ formed both in the $\mathrm{Grt}_{2}$ interior and in between the matrix $\mathrm{Grt}_{2}$ and $\mathrm{Cpx}_{2}$, and the retrograde $\mathrm{Chl}_{4}$ formed from the $\mathrm{Hbl}_{3}$ rim. (F) Relict rutile $\left(\mathrm{Rt}_{2}\right)$ within Ilmenite $\left(\mathrm{Ilm}_{3}\right)$. (G) Most of the $\mathrm{Rt}_{2}$ retrograded to Ilm 3 . (H) The $\mathrm{Grt}_{2}$ was almost completely retrograded to $\mathrm{Hbl}_{3}+\mathrm{Pl}_{3}$, and $\mathrm{Act}_{4}$ formed from the $\mathrm{Hbl}_{3}$ rim. (I) The $\mathrm{Hbl}_{3}$ and $\mathrm{Ilm}_{3}$ lamellae (M3) exsolved from within the $\mathrm{Cpx}_{2}$. (J) The retrograde minerals $\mathrm{Pl}_{3}, \mathrm{Ilm}_{3}$, and $\mathrm{Ttn}_{3}$ lamellae (M3) exsolved from within the $\mathrm{Cpx}_{2}$. (K) The $\mathrm{Cpx}_{2}$ rim retrograded to $\mathrm{Hbl}_{3}$. (L) Ilmenite $\left(\mathrm{Ilm}_{3}\right)+$ hornblende $\left(\mathrm{Hbl}_{3}\right)$ symplectite was possibly retrograded from rutile or high-Al titanite. 

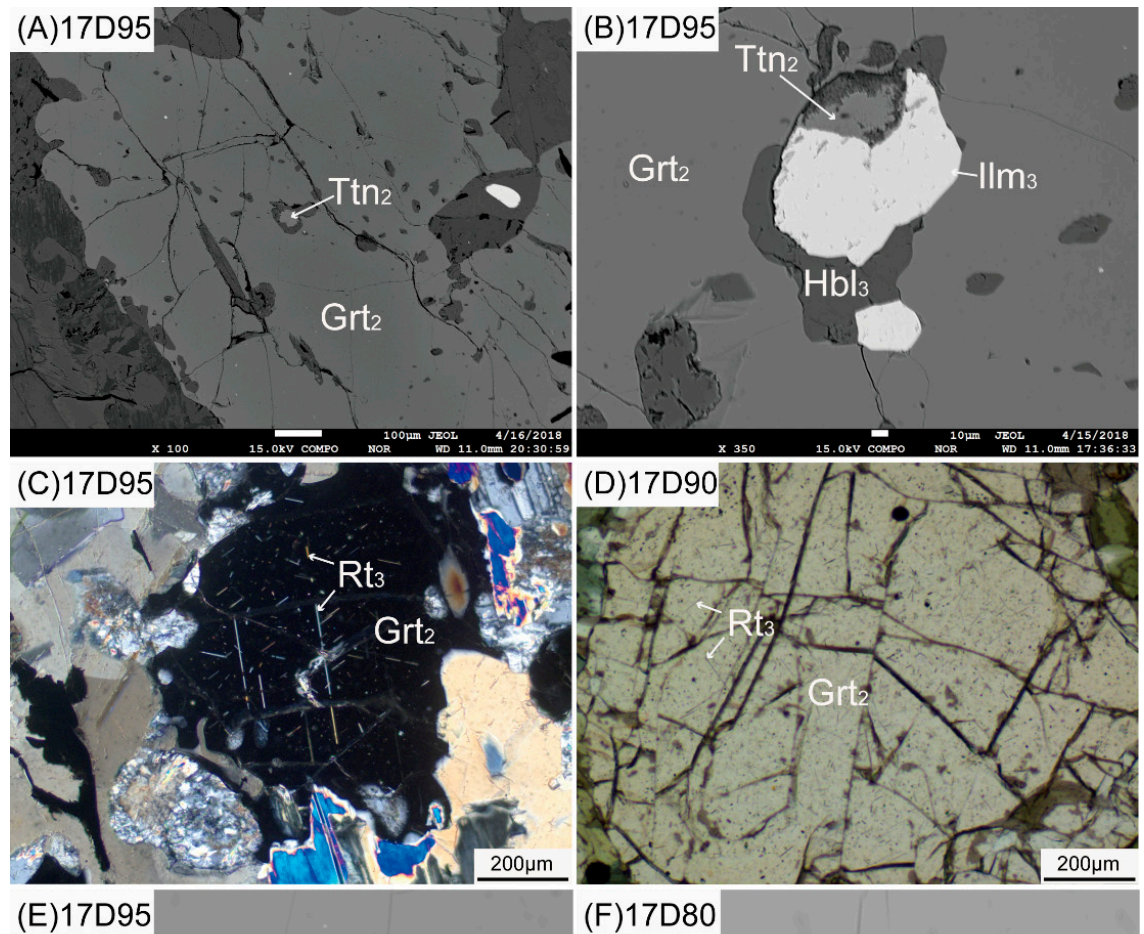

(F)17D80

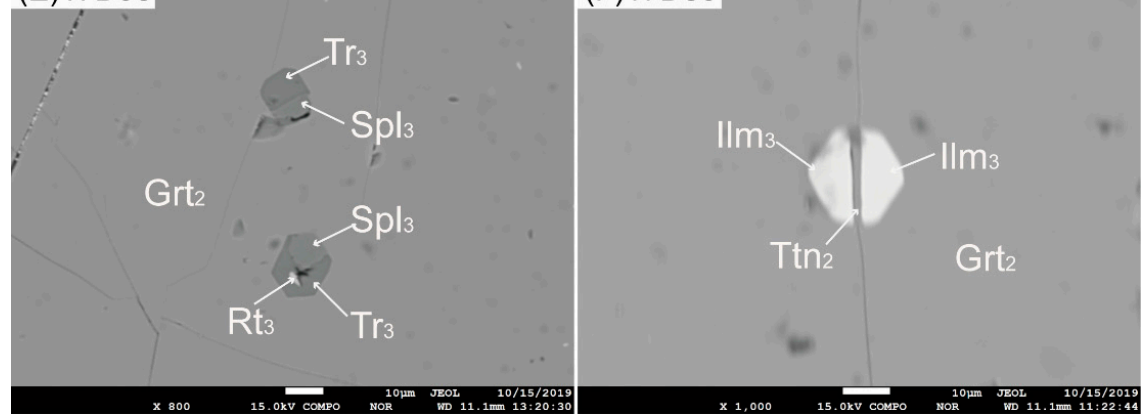

Figure 3. Micropetrographic evidence of ultra-high pressure (UHP) metamorphism. (A) High-Al titanite enclosed in garnet porphyroblast. (B) High-Al titanite rimmed by ilmenite and hornblende within garnet porphyroblast. (C,D) At least three groups of rutile lamellae (the needles) exsolved from within the garnet. (E) Idiomorphic multiple-phase inclusion of spinel (Spl) + tremolite ( $\mathrm{Tr}$ ) \pm rutile (Rt) within garnet. (F) Idiomorphic hexagon ilmenite separated by high-Al titanite from centerline in garnet.

\section{Analytical Methods and Geothermobarometry}

\subsection{Major and Trace Elements Analysis}

Compositional analyses of major elements, backscattered electron (BSE) images, as well as X-ray compositional mapping of minerals were determined by electron microprobe analysis (EMPA) using a JOEL JXA-8230 analyzer at the School of Resource and Environmental Engineering, Hefei University of Technology, China. The analytical conditions were $15 \mathrm{kV}$ accelerating voltage and $20 \mathrm{nA}$ beam current and the counting time was 10-20 s. Usually, $3 \sim 5 \mu \mathrm{m}$ electron beam diameter was used, while $3 \mu \mathrm{m}$ electron beam size was only adopted in analyzing the tiny minerals. Natural minerals were used as standards, and the ZAF program was utilized for matrix corrections. Generally, at least $3 \sim 5$ grains were analyzed for any representative mineral, and 1 60 spots of each grain were probed. Ferric iron contents of both clinopyroxene and garnet were determined by stoichiometric and charge balance criteria [27], while ferric iron content of hornblende was evaluated by the method of Holland and Blundy [28].

Zirconium concentration in titanite was obtained using Agilent 7900 ICP-MS connected to a resolution LR laser system at the Tianjin Institute of Geology and Mineral 
Resources, Chinese Academy of Geological Sciences, China. Laser spot size and frequency were $43 \mu \mathrm{m}$ in diameter and $6 \mathrm{~Hz}$, respectively. Laser energy density was $3 \mathrm{~J} / \mathrm{cm}^{2}$. The trace element content of the titanite was calibrated externally by the glass standard SRM 610 , and ${ }^{43} \mathrm{Ca}(19.25 \%)$ was used for the internal standard. Meanwhile, the data quality was monitored by the glass standard SRM 612, the titanite MKED-1 and the titanite OLT-1. Two sets of calibration and monitoring standards were inserted every 8 sample points. The data was processed by ICPMSDATA version 10.9.

Zirconium concentration in rutile was analyzed by a JEOL JXA-8230 electron microprobe analyzer (EMPA) at the Institute of Mineral Resources, Chinese Academy of Geological Sciences, Beijing, China. Accelerating voltage was set at $15 \mathrm{kV}$ with $100 \mathrm{nA}$ beam current and 1-5 $\mu \mathrm{m}$ beam spot. Counting times for $\mathrm{Zr}, \mathrm{Nb}, \mathrm{Cr}$, and Fe were 200, 200, 100, and 60 s, respectively. Spectroscopic crystals for Zr, Nb, Cr, and Fe were PETH, PETJ, LIFJ, and LIFJ, respectively (corresponding detection limits: 13, 18, 21, and 18 ppm). A $\mathrm{ZrO}_{2}$ standard was used to calibrate the peak position of $\mathrm{Zr}$, and synthetic rutile was used to inspect the zero-concentration of $\mathrm{Zr}$ at the beginning, the middle, and the end of each sequence. Analytical errors were about $\pm 15 \mathrm{ppm}$ at $1 \sigma$ level according to counting statistics [29].

The whole rock major and trace element analyses were performed at the Australian Laboratory Services (ALS), Guangzhou, China, with their analytical method codes of ME-XRF26d and ME-MS81, respectively.

\subsection{SIMS U-Pb Dating of Titanite}

No zircon was found in these samples, possibly due to $\mathrm{SiO}_{2}$-undersaturated bulk composition of these rocks. Therefore, SIMS U-Th-Pb dating of metamorphic titanite was conducted to determine the age of metamorphism. The SIMS U-Th-Pb analyses of titanite were performed using a Cameca IMS-1280HR SIMS at the Institute of Geology and Geophysics, Chinese Academy of Sciences, Beijing, China. The instrument description and analytical procedure for titanite dating are identical to that of dating perovskite [30] and have been described in detail in Li et al. [31] and Ling et al. [32], thus only a brief summary is described here. The $\mathrm{O}^{2-}$ primary ion beam was accelerated at $\sim 13 \mathrm{kV}$, with an intensity of $\sim 9 \mathrm{nA}$. The ellipsoidal spot is about $20 \mu \mathrm{m} \times 30 \mu \mathrm{m}$ in size. The ${ }^{40} \mathrm{Ca}^{48} \mathrm{Ti}^{216} \mathrm{O}_{4}{ }^{+}$peak is used as a reference peak for centering the secondary ion beam, energy, and mass adjustments. A mass resolution of $\sim 7000$ (defined at 50\% peak height) was used. A single electron multiplier was used in ion-counting mode to measure secondary-ion beam intensities by a peak jumping sequence, including isotopes of $\mathrm{Pb}^{+}, \mathrm{Th}^{+}, \mathrm{U}^{+}, \mathrm{ThO}^{+}, \mathrm{UO}^{+}$, and ${ }^{40} \mathrm{Ca}^{48} \mathrm{Ti}^{216} \mathrm{O}_{4}{ }^{+}$ to produce one set of data. Analyses of the standard YQ82 titanite were interspersed with unknown grains. Each measurement consists of 15 cycles, and the total analytical time is $\sim 19 \mathrm{~min}$. Pb/U calibration was performed relative to YQ82 titanite standard $\left({ }^{206} \mathrm{~Pb} /{ }^{238} \mathrm{U}\right.$ age $=1837.6 \mathrm{Ma}$, Li et al. [33]). U and Th concentrations were calibrated against titanite BLR-1 [34]. A long-term uncertainty of $1.5 \%$ (1 $\sigma$ RSD) for ${ }^{206} \mathrm{~Pb} /{ }^{238} \mathrm{U}$ measurements of the standard titanite was propagated to the unknowns, despite that the measured ${ }^{206} \mathrm{~Pb} /{ }^{238} \mathrm{U}$ error in a specific session is generally $\leq 1 \%(1 \sigma$ RSD). A Tera-Wasserburg [35] plot was constructed with common lead uncorrected data to deduce the common lead composition, and then a ${ }^{207} \mathrm{~Pb}$-based common lead correction method was conducted to single analysis. Data reduction was carried out using the Isoplot/Ex v. 2.49 program [36]. Uncertainties on individual analysis in data table are reported at $1 \sigma$ level. The final $\mathrm{U}-\mathrm{Pb}$ age result is quoted with $95 \%$ confidence level.

\subsection{Geothermobarometry}

Metamorphic P-T conditions of the peak metamorphism (M2) were determined by the garnet-clinopyroxene geothermometer [37] coupled with the garnet-clinopyroxene geobarometer [38], using the averaged chemical composition of garnet (plateau cores) and reintegrated (Samples 17D78 and 17D80)/averaged (Samples 17D90 and 17D95) chemical composition of clinopyroxene. Although this geobarometer was experimentally calibrated 
for mantle eclogite, the chemical compositions of the natural rocks reported in this work are similar to those of the experimental run products [38]. The accuracy of this geobarometer is estimated to be \pm 4 kbar [38]. The prograde (M1) and retrograde (M3) assemblages mainly consist of plagioclase and hornblende but without quartz, therefore, $P-T$ conditions of the M1 and M3 assemblages were estimated by the monomineralogic hornblende geothermobarometers, with $P$ - $T$ uncertainties of $\pm 37^{\circ} \mathrm{C}$ and $\pm 1.2 \mathrm{kbar}$, respectively [39].

For comparison, $\mathrm{Zr}$-in-titanite [40] and Zr-in-rutile [41] geothermometers were employed to determine the temperature conditions. Because the activity of the $\mathrm{SiO}_{2}$ and $\mathrm{ZrO}_{2}$ components cannot be determined due to the absence of quartz/coesite and zircon in these samples, we assumed a series of activities of $\mathrm{SiO}_{2}$ (i.e., 0.01, 0.05, 0.1, and 0.2). Meanwhile, we set the activity of $\mathrm{TiO}_{2}$ component to be unity because of the existence of rutile. Jiao et al. [42] concluded that if the assumed activity of $\mathrm{SiO}_{2}$ and pressure are appropriate, the geothermometers of Watson et al. [43], Ferry and Watson [41] and Tomkins et al. [44] can yield similar temperatures, but the geothermometer of Zack et al. [45] usually yields higher temperatures of $\sim 125^{\circ} \mathrm{C}$ than others. In our case, due to severe retrogradation of matrix rutile and the marked differences of $\mathrm{Zr}$ concentration between rutile in the inclusion and matrix, we do not assure if the zirconium in rutile records temperatures corresponding to which pressure conditions (prograde, peak, or retrograde). It is noted that the rutile of UHP eclogite in the Dabie-Sulu orogenic belt usually records much lower peak temperatures than other geothermometers even if the pressure effects were considered. This possibly indicates zirconium content in rutile might only represent a buffering state of rutile after retrograde metamorphism in the amphibolite facies [29]. Therefore, we preferred the Zr-inrutile geothermometer of Ferry and Watson [41], which includes the activity of $\mathrm{SiO}_{2}$ and is unrelated to pressure. While applying the Zr-in-titanite thermometer [40], there are two possibilities. One possibility is that if titanite was formed during the retrograde stage, the input pressure for $\mathrm{Zr}$-in-titanite geothermometer calculation should be that of retrograde metamorphism. Another possibility is that the titanite was retrograded from high-Al titanite, in this case, the input pressure for $\mathrm{Zr}$-in-titanite geothermometer calculation should be corresponding to peak metamorphism. Due to varying zirconium concentrations in rutile, it is uncertain to what geological process the temperatures recorded by zirconium in rutile correspond. Therefore, we cannot combine these two geothermometers as suggested by Hayden et al. [40]. Instead, we input pressures of both the peak metamorphic conditions (if titanite was retrograded from high-Al titanite) and the retrograde metamorphic conditions (if titanite was newly crystallized in retrograde stage) to calculate the temperature conditions recorded by zirconium in titanite.

\section{Results}

\subsection{Mineral Chemistry}

The representative major elements of minerals are listed in Tables S1-S4, and the trace element concentrations of rutile and titanite as well as the calculated temperatures are listed in Tables S5 and S6, respectively. The garnet $\left(\mathrm{Grt}_{2}\right)$ is chemically homogeneous in each sample and is mainly consisting of almandine $\left[\mathrm{X}_{\mathrm{Alm}}=\mathrm{Fe}^{2+} /\left(\mathrm{Ca}+\mathrm{Fe}^{2+}+\mathrm{Mg}+\mathrm{Mn}\right)=\right.$ $0.34 \sim 0.54]$, pyrope $\left[\mathrm{X}_{\operatorname{Prp}}=\mathrm{Mg} /\left(\mathrm{Ca}+\mathrm{Fe}^{2+}+\mathrm{Mg}+\mathrm{Mn}\right)=0.19 \sim 0.48\right]$, and grossular $\left[\mathrm{X}_{\mathrm{Grs}}=\right.$ $\left.\mathrm{Ca} /\left(\mathrm{Ca}+\mathrm{Fe}^{2+}+\mathrm{Mg}+\mathrm{Mn}\right)=0.18 \sim 0.32\right]$ but negligible spessartine $\left[\mathrm{X}_{\mathrm{Sps}}=\mathrm{Mn} /\left(\mathrm{Ca}+\mathrm{Fe}^{2+}+\right.\right.$ $\mathrm{Mg}+\mathrm{Mn})]$ components. Such garnet is chemically different from those in mantle xenolith or eclogite, which have a much higher $\mathrm{MgO} / \mathrm{FeO}$ ratio and higher $\mathrm{Cr}$ content. Negligible chemical zonation of the garnet was found. In the very rim of the garnet, the $\mathrm{Fe} \#[=\mathrm{Fe} /(\mathrm{Fe}$ $+\mathrm{Mg}$ )] value increases slightly (Table S7; Figure 4 and Figure S1), indicative of post-peak Fe-Mg diffusion between the garnet rim and adjacent clinopyroxene and/or decomposition of the garnet rim [46]. This is also demonstrated by micropetrograph, in which the garnet rim was consumed and replaced by retrograde assemblages (Figure 2A,B,E).

Chemical analytical profiles (Table S8) suggest that the clinopyroxene $\left(\mathrm{Cpx}_{2}\right)$ is almost chemically homogeneous in each sample and is essentially diopside based on the classification of Morimoto [47] (Figure 5) with negligible jadeite fraction. Due to exsolution, however, 
the chemical composition of individual $\mathrm{Cpx}_{2}$ shows some variations. Although the $\mathrm{Mg}^{2+}$ and $\mathrm{Fe}^{2+}$ cations of the $\mathrm{Cpx}_{2}$ grains are generally homogeneous, $\mathrm{Al}^{3+}$ and $\mathrm{Ca}^{2+}$ cations show somewhat variations (Figures S2-S5), thus the reintegrated chemical composition of clinopyroxene was used to estimate peak $P$ - $T$ conditions.
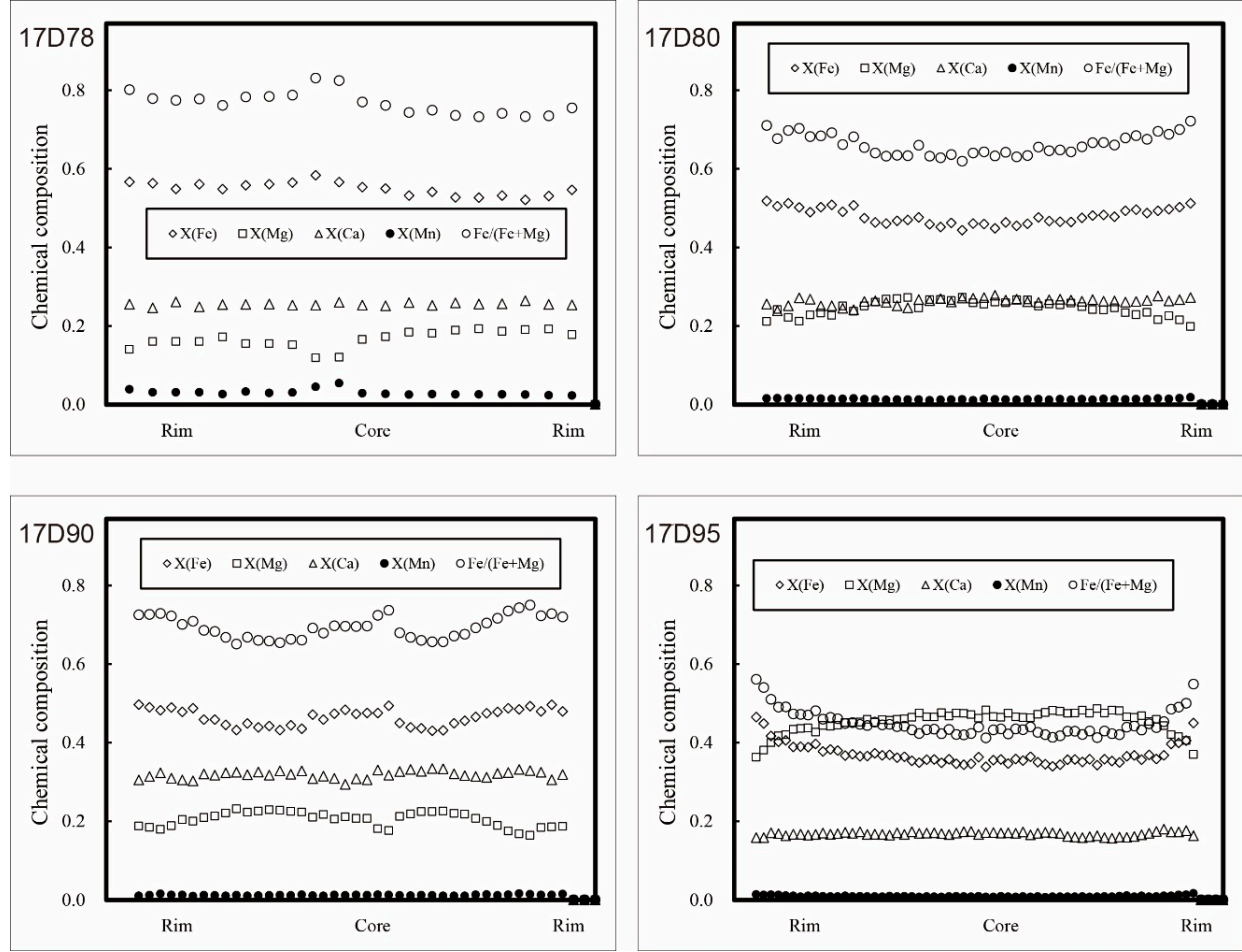

Figure 4. Chemical compositional profiles of the garnet porphyroblast in samples 17D78, 17D80, 17D90, and 17D95.

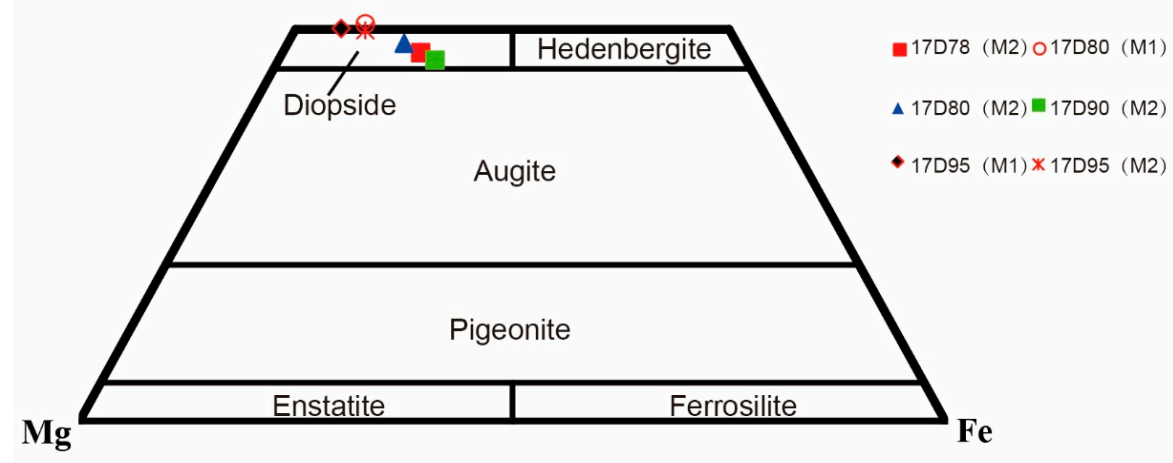

Figure 5. Classification of clinopyroxene in different samples (classification of Morimoto [47]).

High-Al titanite contains remarkable $\mathrm{Al}_{2} \mathrm{O}_{3}(8.2 \sim 10.2 \mathrm{wt} \%)$ and $\mathrm{F}$ contents $(1.3 \sim 2.8 \mathrm{wt} \%)$ as listed in Table S4, which possibly imply high pressure to UHP metamorphism [48-51]. The titanite selected for dating and trace element analysis contains relatively lower $\mathrm{Al}_{2} \mathrm{O}_{3}$ contents $(1.09-2.86 \%)$. The rutile enclosed in garnet contains much higher zirconium contents ( $\sim 3003$ to $\sim 3338 \mathrm{ppm}$ ) than those in the matrix (which usually retrograde to ilmenite, $\sim 13$ to $\sim 160 \mathrm{ppm}$ ), this phenomenon might be related to severe retrograde in matrix, which caused rutile to release the vast majority of zirconium [29]. 


\subsection{U-Pb Dating Results of Titanite}

The SIMS U-Th-Pb analytical data of titanite separated from garnet clinopyroxenite are listed in Table S9 and the BSE images of titanite are shown in Figure S6. The titanite images are homogeneous in sample 17D78, while in samples 17D90 and 17D95 titanite shows some textural variations. The resulted $\mathrm{U}-\mathrm{Pb}$ ages of the metamorphic titanite from samples 17D78 and 17D95 are $\sim 370 \pm 9 \mathrm{Ma}$ and $\sim 389 \pm 8 \mathrm{Ma}$ (Figure 6), respectively, while sample 17D95 records a younger age of $\sim 362 \pm 7 \mathrm{Ma}$. The ages of titanite of sample 17D90 are scattered and younger and have an age peak of $\sim 253 \pm 14 \mathrm{Ma}$.
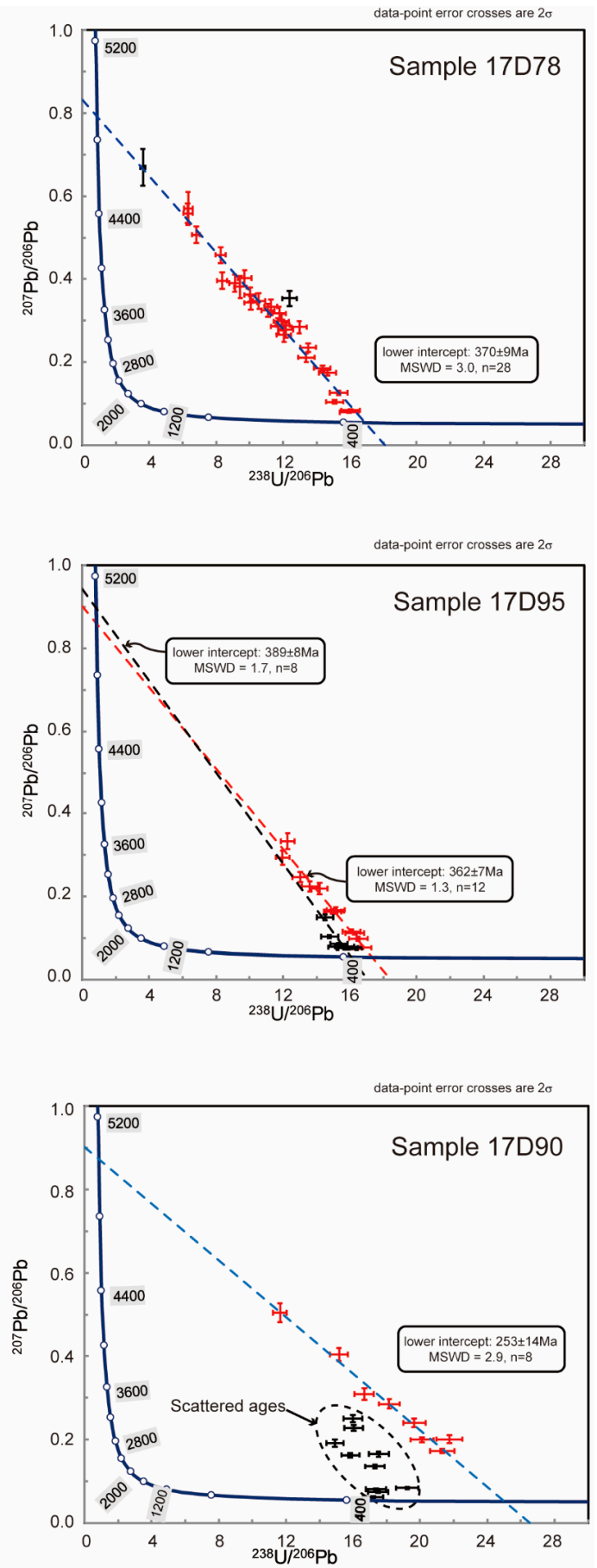

Figure 6. U-Pb concordia diagram of analyzed titanite separated from the garnet clinopyroxenite samples 17D78, 17D95, and 17D90. Data are plotted at $2 \sigma$ level, and uncertainties on lower intercept ages are on the $95 \%$ confidence. 


\subsection{Metamorphic P-T Paths}

The obtained $P-T$ results are listed in Table S10. Metamorphic $P-T$ path of sample $17 \mathrm{D} 78$ passes from $662{ }^{\circ} \mathrm{C} / 5.4 \mathrm{kbar}(\mathrm{M} 1)$ through $789^{\circ} \mathrm{C} / 28 \mathrm{kbar}(\mathrm{M} 2)$ to $621^{\circ} \mathrm{C} / 4.6 \mathrm{kbar}$ (M3). As for the other three samples, metamorphic $P-T$ paths were estimated as follows, respectively: sample 17D80, $902{ }^{\circ} \mathrm{C} / 38.2 \mathrm{kbar}(\mathrm{M} 2) \rightarrow 656^{\circ} \mathrm{C} / 5.4 \mathrm{kbar}(\mathrm{M} 3) ;$ sample 17D90, $695^{\circ} \mathrm{C} / 7.2 \mathrm{kbar}(\mathrm{M} 1) \rightarrow 868^{\circ} \mathrm{C} / 31.8 \mathrm{kbar}(\mathrm{M} 2) \rightarrow 669^{\circ} \mathrm{C} / 6.0 \mathrm{kbar}(\mathrm{M} 3)$; and sample $17 \mathrm{D} 95,918^{\circ} \mathrm{C} / 41.3 \mathrm{kbar}(\mathrm{M} 2) \rightarrow 631^{\circ} \mathrm{C} / 5.6 \mathrm{kbar}(\mathrm{M} 3)$. The retrieved metamorphic $P-T$ paths of the garnet clinopyroxenite enclaves are all clockwise (Figure 7) [52-55]. It should be stated that the peak metamorphism (except for sample 17D78) lies in the coesite or even the diamond stability field (Figure 7), implying UHP metamorphism. The UHP conditions are further supported by the occurrence of at least three groups of aligned rutile lamellae (Rt3) exsolved from within the garnet (Figure 3C,D) and chemically homogeneous high-Al titanite $\left(\mathrm{Ttn}_{2}\right)$ enclosed in the garnet (Figure $\left.3 \mathrm{~A}, \mathrm{~B}\right)$, being characterized by $\mathrm{X}_{\mathrm{Al}}[=\mathrm{Al} /(\mathrm{Al}$ $\left.\left.+\mathrm{Fe}^{3+}+\mathrm{Ti}\right)\right]=0.25 \sim 0.29$. These two mineralogical characteristics together indicate UHP metamorphism [26,56,57].
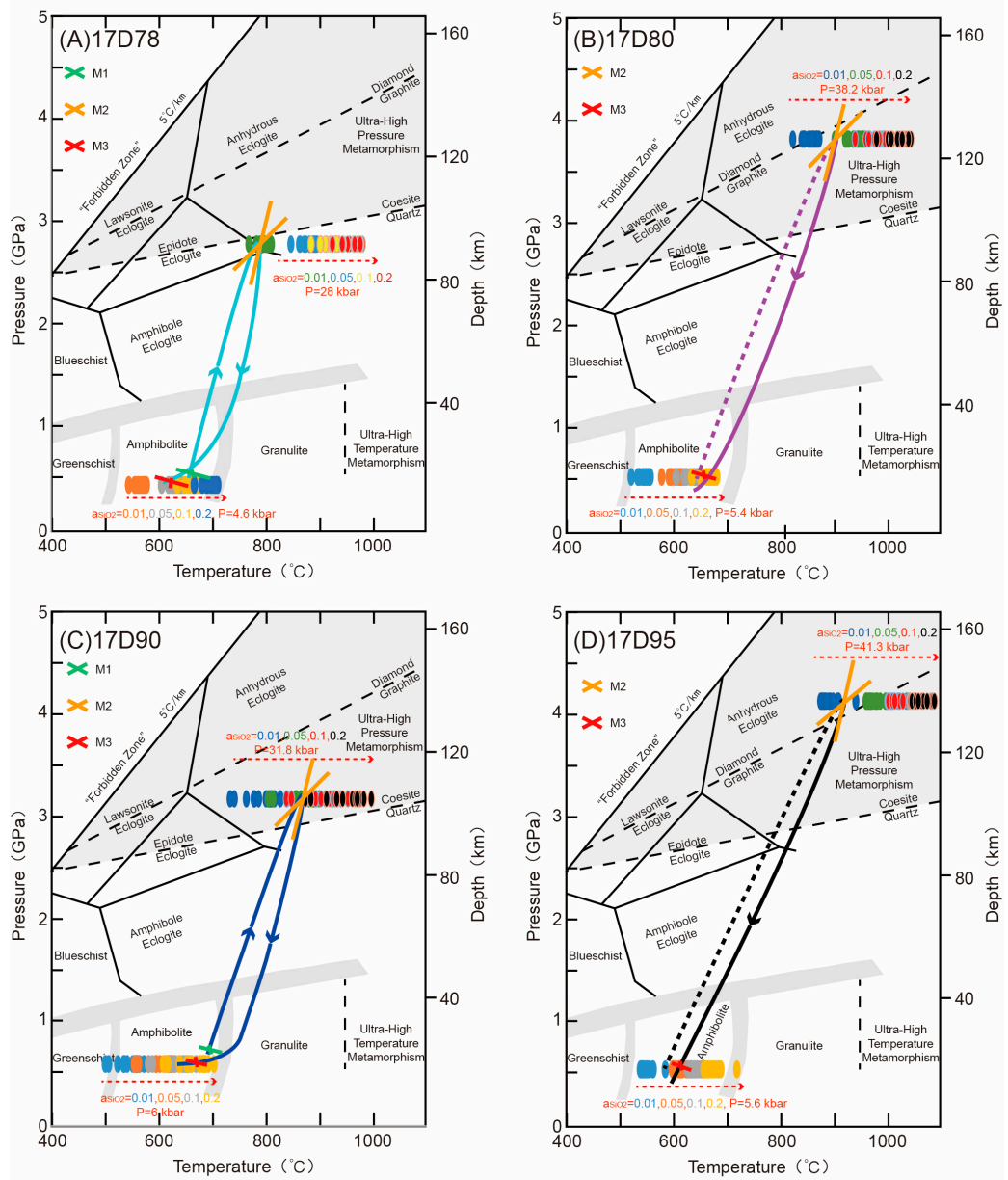

Figure 7. Metamorphic $P-T$ paths of the four garnet clinopyroxenite samples. (A) Sample 17D78. (B) Sample 17D80. (C) Sample 17D90. (D) Sample 17D95. In each figure, M1, M2, and M3 represent the prograde, peak, and retrograde metamorphism, respectively. The red dotted arrows, and their neighboring annotations and different colored ellipses represent the temperature results obtained by $\mathrm{Zr}$-in-titanite geothermometer [40] with variable activities of $\mathrm{SiO} 2(0.01,0.05,0.1$, and 0.2$) . P=28 \mathrm{kbar}$ means that the pressure for $\mathrm{Zr}$-in-titanite calculation was set as $28 \mathrm{kbar}$. The grey thick and black thin boundaries of metamorphic facies are taken from O'Brien and Rötzler [52] and Winter [53], respectively. The diamond $=$ graphite and quartz $=$ coesite polymorph transition curves are taken from Kennedy and Kennedy [54] and Bose and Ganguly [55], respectively. 


\section{Discussion}

Although no coesite or diamond was found in the Dunhuang orogenic belt, UHP metamorphism of the orogen is evidenced by the garnet clinopyroxenite enclaves from the Daquan area. However, problems concerning protolith, micropetrography, $P-T$ computation, and geochronology should be discussed in detail in order to assess the validity of UHP metamorphism.

\subsection{Protolith of Garnet Clinopyroxenite}

The Al-rich titanite was usually reported in skarn, calcsilicate, or impure marble [49,58,59], which are all calcic rocks. However, skarn or calcsilicate always consists of Ca-rich minerals including garnet, diopside, wollastonite, scapolite, vesuvianite, calcite, quartz, and the garnet is mainly consisting of andradite and grossular components [60,61]. Therefore, the garnet clinopyroxenite reported in this work is obviously not skarn or calcsilicate because both the mineral assemblages and chemical composition of the garnet undoubtedly do not match that of skarn or calcsilicate.

The geochemical features can be used to discuss the protoliths and possible tectonic setting of garnet clinopyroxenite. The geochemical properties of the four representative samples (Table S11) suggest that their protoliths were possibly sub-alkaline basalt, according to the classification diagram of Pearce [62] (Figure 8A). In the $\mathrm{Zr}$ versus Ti discrimination diagram (Figure 8B) of Pearce [63], two samples (17D80 and 17D90) are classified as island arc basalt (IAB) and the other two samples (17D78 and 17D95) as mid-ocean ridge basalt (MORB) in origin. From the chondrite-normalized rare earth element (REE) pattern and primitive mantle-normalized spidergram [64], two groups of different characteristics can also be seen (Figure 9). One group is represented by samples 17D78 and 17D95, another is shown by samples 17D80 and 17D90, which are consistent with the discrimination diagrams. Therefore, the garnet clinopyroxenites are possibly different in origin. However, it is noted that $\mathrm{SiO}_{2}$ contents of the rocks are $42.2 \mathrm{wt} \%$ (sample 17D78), $44.2 \mathrm{wt} \%$ (sample 17D80), $43.6 \mathrm{wt} \%$ (sample 17D90), and to $47.7 \mathrm{wt} \%$ (sample 17D95), respectively. Consequently, we inferred that the bulk rock compositions had possibly been modified in the metamorphism, or alternatively, the rocks experienced chemical weathering or metasomatism prior to metamorphism. Meanwhile, the inclusion assemblage (M1) suggests the prograde metamorphism $[65,66]$, in this case probably indicating early stages in the subduction process.
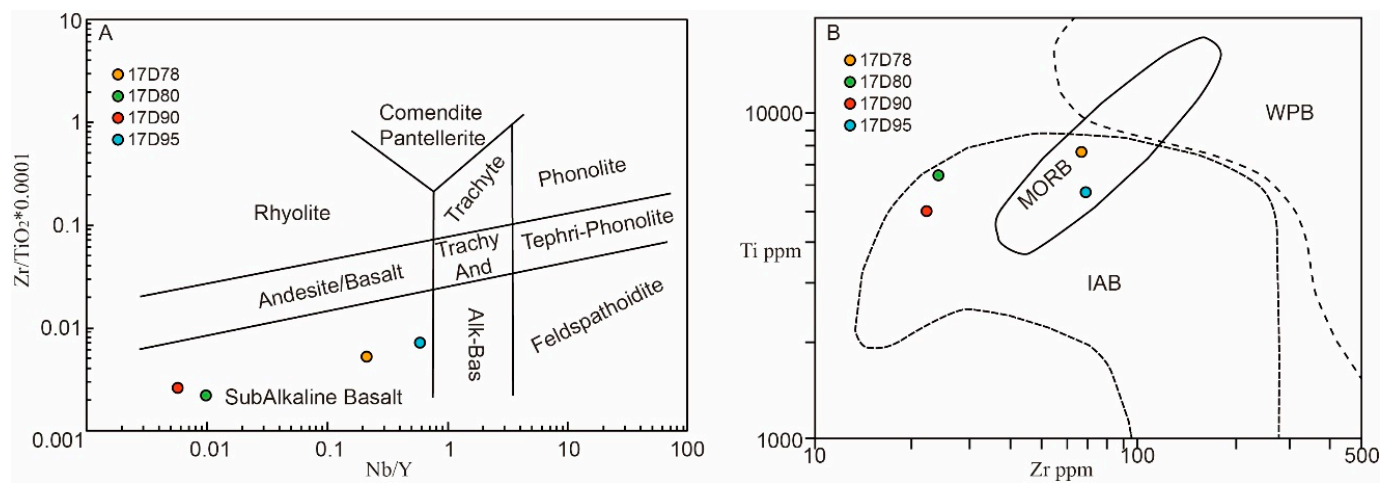

Figure 8. Classification of protoliths of garnet clinopyroxenite. (A) $\mathrm{Nb} / \mathrm{Y}$ vs. $\mathrm{Zr} / \mathrm{TiO}_{2}$ plot (after Pearce [62]); and (B) $\mathrm{Zr}$ vs. Ti discrimination diagram (after Pearce [63]). 

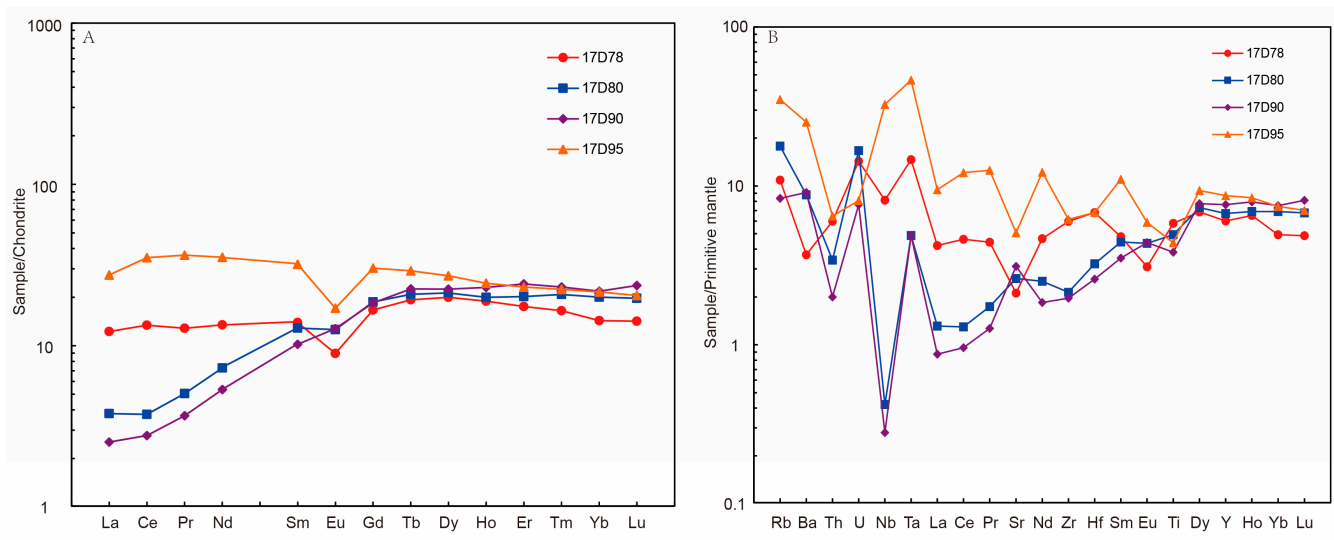

Figure 9. Chondrite-normalized REE patterns (A) and primitive mantle-normalized spidergrams (B) for garnet clinopyroxenites. The chondrite and primitive mantle values are from Sun and McDonough [64].

The clinopyroxene of this work is essentially $\mathrm{Na}_{2} \mathrm{O}-\mathrm{Al}_{2} \mathrm{O}_{3}$-deficient $\left(\mathrm{Na}_{2} \mathrm{O}<0.35 \mathrm{wt} \%\right.$, $\mathrm{Al}_{2} \mathrm{O}_{3}<3.0 \mathrm{wt} \%$ ) and the jadeite phase component of clinopyroxene is negligible. Therefore, although the chemical compositions of the garnet and clinopyroxene somewhat overlap that of mantle xenolith and eclogite, the present garnet clinopyroxenite is neither mantle xenolith nor mantle eclogite or crustal eclogite. Instead, the protoliths might be basic or ultrabasic volcanics of different origin, which were subducted into great depths and experienced UHP metamorphism, then amalgamated into the same crustal level and captured by the granitic pluton.

\subsection{UHP Metamorphism Evidenced by Reaction Textures}

The rocks contain high-Al titanite enclosed in the garnet and preserve three groups of aligned rutile lamellae exsolved from within the garnet (Figure 3). However, it is noted that high-Al titanite also appears in low- $P$ metamorphic rocks $[58,59]$, and the activity of $\mathrm{F}$ and bulk-rock composition also affect the $\mathrm{Al}$ and $\mathrm{F}$ contents of titanite $[49,51,58]$. However, the reported low- $P$ rocks are essentially skarn, which contains considerable calcite and also contains negligible pyrope component in garnet. Furthermore, no aligned rutile lamellae in the garnet of skarn were found. Castelli and Rubatto [59] suggested that if there are appropriate bulk compositions with high fluorine activities, high-Al titanite could also be formed at high- $T$ rather than high- $P$ conditions. However, their modeling is based on the carbonate $\left(\mathrm{CaO}-\mathrm{TiO}_{2}-\mathrm{SiO}_{2}-\mathrm{H}_{2} \mathrm{O}-\mathrm{CO}_{2}\right)$ system, differently from our samples.

Actually, Frost et al. [67] suggested that the stability of titanite in metabasites is limited in certain $P$ - $T$ conditions, which are constrained by several reactions. Our high-Al titanite are obviously out of their prediction, and the reasons may be as follows: (1) the reactions they supposed would not occur in our bulk rock composition; (2) the $P$-T diagram they represented was restricted to $P<12 \mathrm{kbar}$ and $T<700{ }^{\circ} \mathrm{C}$, which show no trend in high- $T$ and high- $P$ domains; and (3) they only considered common titanite in metabasites but excluding high-Al titanite.

Oberti et al. [68] suggested that the An-rich plagioclase could impede the stabilization of high-Al titanite, thus the occurrence of anorthite in prograde and retrograde assemblages indicates that high-Al titanite formed during peak metamorphism, coexisting with garnet which exsolved rutile lamellae. However, except for UHP metamorphism, the rutile lamellae exsolved from within the garnet could also be formed at high- $T$ conditions $\left(>900{ }^{\circ} \mathrm{C}\right.$, especially in high- $P$ granulite) [69]. Actually, experiments show that the $\mathrm{Al}$ content of titanite increases with $P$ and decreases with T $[48,70,71]$. In this regard, in spite of the peak high- $T$ condition, the effect of $P$ should still play a major role, otherwise, Al-rich titanite should not exist in the peak assemblages. 


\subsection{UHP Metamorphism Confirmed by Geothermobarometers}

For estimating metamorphic $P-T$ conditions of garnet clinopyroxenite, the garnetclinopyroxene geothermometer and the garnet-clinopyroxene geobarometer are quite irreplaceable. At least 30 versions of the garnet-clinopyroxene Fe-Mg exchange geothermometer have been calibrated in the past five decades. The most recent version of this geothermometer [37] was calibrated based on data of phase equilibrium experiments in mafic and ultramafic systems, and the standard error is relatively small $\left( \pm 74^{\circ} \mathrm{C}\right)$ in reproducing all the available experimental data, in the wide experimental $P-T$ ranges of $800 \sim 1820^{\circ} \mathrm{C} / 15 \sim 75 \mathrm{kbar}$ [37]. It is noted that previous formulations of the garnetclinopyroxene geothermometer are inconsistent with the experimental data set, i.e., they either underestimate $T \mathrm{~s}$ by about $100{ }^{\circ} \mathrm{C}$ when $T>1300{ }^{\circ} \mathrm{C}$ or overestimate $T$ s by $100 \sim 200{ }^{\circ} \mathrm{C}$ when $T<1300^{\circ} \mathrm{C}$ [37]. Furthermore, former garnet-clinopyroxene geothermometers tend to overestimate $T \mathrm{~s}$ for high-Ca garnet $\left(\mathrm{X}_{\mathrm{Grs}}=0.30 \sim 0.50\right)$, as found by Nakamura [37]. Because chemical compositions of garnet and clinopyroxene of this work fall within the calibration range of this geothermometer [37] and because of its relatively high accuracy, Nakamura's geothermometer [37] was adopted in this work.

In order to estimate metamorphic $P_{\mathrm{s}}$ of the garnet-clinopyroxene and mantle eclogite, several versions of the garnet-clinopyroxene geobarometer [38,72-75] have been calibrated. The widely used garnet-clinopyroxene geobarometer was calibrated in the mafic or ultramafic system and is applicable to mantle eclogite with high-Na-Al clinopyroxene, or garnet clinopyroxenite with low-Na-Al clinopyroxene [38], which is the case for rocks reported in this work. In the computation, activities of jadeite and acmite phase components in clinopyroxene are not needed and, therefore, errors of chemical compositions of low-Na-Al clinopyroxene do not translate to larger pressure errors. Among different versions of the garnet-clinopyroxene geobarometer, the geobarometer of Beyer et al. [38] was calibrated based on phase equilibrium experimental data in the wide $P$ - $T$ ranges of $2 \sim 7 \mathrm{GPa} /$ $900 \sim 1550{ }^{\circ} \mathrm{C}$. Standard error of this barometer is approximately $\pm 4 \mathrm{kbar}$ [38], and it is the most accurate version at present. Chemical compositions of our minerals are similar to the experimental run products in calibrating this geobarometer and, therefore, this barometer was applied to our samples. It should be stated that the $\mathrm{Cr}_{2} \mathrm{O}_{3}$ components are negligible for our garnet and clinopyroxene, and thus the $\mathrm{Cr}_{2} \mathrm{O}_{3}$-based garnet-clinopyroxene geobarometers [76-78] cannot be applied.

The yielded $P$-T conditions of peak metamorphism lie in the UHP metamorphic region for samples 17D95, 17D90, and 17D80, or high- $P$ region for sample 17D78, which lies slightly lower than the coesite-quartz transition curve (Figure 7). However, when considering standard error ( $\pm 4 \mathrm{kbar}$ ) of the present garnet-clinopyroxene geobarometer [38], it can be concluded that peak metamorphism occurred at UHP conditions for all the samples.

In addition, trace element geothermometers were also applied to garnet clinopyroxenite. However, the zirconium component in matrix rutile records much lower temperature $\left(<500{ }^{\circ} \mathrm{C}\right.$, Table S5); even if the activity of $\mathrm{SiO}_{2}$ is assumed to be unity, the yielded temperatures are also lower than $600^{\circ} \mathrm{C}$, far below from either the peak or retrograde metamorphic temperatures. The rutile inclusions contain much higher zirconium content, and records $\sim 590^{\circ} \mathrm{C}$ to $\sim 710^{\circ} \mathrm{C}$ temperature conditions when the activity of $\mathrm{SiO}_{2}$ was assumed to be $0.05-0.2$, possibly corresponding to prograde metamorphism (if no zirconium was released from rutile). On the other hand, the results of $\mathrm{Zr}$-in-titanite geothermometer are consistent with the $P$ - $T$ conditions obtained by garnet-clinopyroxene geothermobarometers $[37,38]$ or monomineralogic hornblende geothermobarometers [39] when the activities of $\mathrm{SiO}_{2}$ are appropriately set to be 0.01-0.2 (Table S6; Figure 7). If the analyzed titanite was altered from high-Al titanite when inputting lower pressures (e.g., $15 \mathrm{kbar}$ ) to the $\mathrm{Zr}$-in-titanite geothermometer [40], the retrieved temperatures are lower than $850{ }^{\circ} \mathrm{C}$ when assuming the activity of $\mathrm{SiO}_{2}$ to be 0.2 , but this result is in conflict with the rutile exsolution in garnet and high-Al titanite. Therefore, we used the pressures resulted from garnet-clinopyroxene geobarometer [38] to compute temperatures using the Zr-in-titanite geothermometer [40] and obtained nearly similar temperature results (Table S6; Figure 7) to the garnet-clinopyroxene 
geothermometer [37]. This possibly indicates that titanite (altered high-Al titanite) was once at equilibration with garnet and clinopyroxene. If the analyzed titanite was recrystallized during retrograde, it might be equilibrated with the retrograde assemblages, thus we input the pressures obtained by monomineralogic hornblende geothermobarometers [39], and obtained similar temperature results (Table S6; Figure 7) with the monomineralogic hornblende geothermobarometers [39]. Actually, we may see large temperature variations obtained by $\mathrm{Zr}$-in-titanite geothermometer (Figure 7), even if the activity of $\mathrm{SiO}_{2}$ and pressure are fixed. This is possible because that titanite was altered and zirconium was removed partially from titanite [79], leading to variable $\mathrm{Zr}$ concentrations in titanite.

\subsection{Significance of Titanite $\mathrm{U}-\mathrm{Pb}$ Ages}

The closure temperature of $\mathrm{U}-\mathrm{Pb}$ system in titanite is about $660 \sim 700{ }^{\circ} \mathrm{C}$ [80] or $750 \sim 790{ }^{\circ} \mathrm{C}$ [81], and $\mathrm{Pb}$ diffusion in titanite seems to be negligible even at about $800{ }^{\circ} \mathrm{C}$ [82], which are somewhat lower than the peak metamorphic temperatures $\left(790 \sim 920{ }^{\circ} \mathrm{C}\right)$. Furthermore, the dated titanite is not Al-rich, suggesting that the dated titanite might be recrystallized or altered during cooling/retrograde. Therefore, the U-Pb ages of the titanite ( 389-370 Ma) possibly record the recrystallization or resetting during the cooling/retrograde period after the peak UHP metamorphic event, i.e., timing of tectonic exhumation, postdating but possibly close to the peak metamorphism.

\subsection{Possible Fast Exhumation of the UHP Metamorphic Rocks}

It is generally believed that UHP rocks should experience fast tectonic exhumation from great depth, otherwise the UHP assemblages may be replaced by lower- $P$ assemblages. In fact, the metamorphic $P-T$ paths of the garnet clinopyroxenite (Figure 7) also suggest relatively rapid uplift, albeit the retrograde $P$ - $T$ paths are hybrid of the western Alpine and Franciscan types [83]. Furthermore, large differences in the peak metamorphic pressures among these samples suggest that these rocks were subducted to different depths and were later amalgamated at the same crustal level during tectonic exhumation.

Although the UHP rocks analyzed here were found within a single granitic pluton, it is reasonable to infer that other UHP rocks are likely buried in the deep root of the Dunhuang orogenic belt. Furthermore, it is found that both medium and high $P / T$ metamorphism occurred in this orogen in the Silurian to Devonian periods [15-19]. The UHP garnet clinopyroxenite reported in this contribution further demonstrates that different metamorphic $P / T$ facies series may prevail in the same orogenic belt.

\section{Conclusions}

Three to four stages of metamorphic mineral assemblages are preserved in the garnet clinopyroxenite enclaves within a granitic pluton in the northeastern Paleozoic Dunhuang orogenic belt, northwestern China. The protoliths of the garnet clinopyroxenite are inferred to be basic or ultrabasic volcanic rocks. The peak metamorphism $\left(870 \sim 920{ }^{\circ} \mathrm{C} / 32 \sim 41 \mathrm{kbar}\right)$ occurred in the coesite or even the diamond stability field, and the concurrence of the high-Al titanite and at least three groups of aligned rutile lamellae exsolved from the garnet further confirm the UHP metamorphic event. Clockwise metamorphic $P-T$ paths of the garnet clinopyroxenite were retrieved, indicative of subduction process. SIMS U-Pb dating of metamorphic titanite indicates that the tectonic exhumation of the ultra-high pressure metamorphic rocks might have occurred in the Devonian period ( $389-370 \mathrm{Ma})$, postdating but possibly approaching very near the peak UHP metamorphism. It should be noted that both medium- and high- $P / T$ facies series metamorphism occurred in this Paleozoic orogen. Furthermore, it is reasonable to infer that most of the UHP rocks are buried in depth, possibly in the deep root of this orogen. 
Supplementary Materials: The following are available online at https:/ /www.mdpi.com/2075-163 X/11/2/117/s1, Figure S1: X-ray compositional mapping of $\mathrm{MnO}, \mathrm{MgO}, \mathrm{FeO}$, and $\mathrm{CaO}$ components of representative garnet porphyroblast in samples 17D80, 17D90, and 17D95, Figure S2: EMPA analytical transverses of clinopyroxene (sample 17D78), Figure S3: EMPA analytical transverses of clinopyroxene (sample 17D80), Figure S4: EMPA analytical transverses of clinopyroxene (sample 17D90), Figure S5: EMPA analytical transverses of clinopyroxene (sample 17D95), Figure S6: Backscattered electron images of titanite separated from garnet clinopyroxenite samples for SIMS U-Pb dating. (a) Sample 17D78. (b) Sample 17D95. (c) Sample 17D90. The circles with red figures represent analytical spots. The yellow numbers are the respective 207Pb-based common lead corrected ages involved in the calculation for samples 17D78 and 17D90, while the white and yellow numbers are the respective 207Pb-based common lead corrected ages both involved in the calculation for sample 17D95, and obtained the younger and older mean ages, respectively, Table S1: Chemical compositions of the representative minerals in sample 17D78, Table S2: Chemical compositions of the representative minerals in sample 17D80, Table S3: Chemical compositions of the representative minerals in sample 17D90, Table S4: Chemical compositions of the representative minerals in sample 17D95, Table S5: EMPA analysis of rutile and temperature calculation results with different $\mathrm{aSiO}_{2}$, Table S6: $\mathrm{Zr}$ contents in titanite and calculated temperatures with various $\mathrm{aSiO}_{2}$, Table S7: Chemical compositional profiles of the garnet, Table S8: Chemical compositional profiles of the clinopyroxene, Table S9: SIMS $\mathrm{U}-\mathrm{Th}-\mathrm{Pb}$ analytical data for titanite from garnet clinopyroxenite, Table S10: Pressure-temperature $(P-T)$ conditions retrieved for the different metamorphic stages of garnet clinopyroxenite, Table S11: Bulk-rock compositions for both major and trace elements of garnet clinopyroxenite.

Author Contributions: C.-M.W., H.W., Z.L., Q.Z., and M.-Y.S. did the field investigation; Z.L., Q.Z., and J.-H.L. carried all the experiments; Z.L, J.-S.L., Q.Z., and J.-H.L. processed the data; Z.L. drew all the figures; Z.L. and C.-M.W. wrote the original manuscript and all the authors involved in the writing and agreed to the submission of the manuscript. All authors have read and agreed to the published version of the manuscript.

Funding: This work was supported by the National Natural Science Foundation of China (41730215) and the Key Research Program of Frontier Sciences from the Chinese Academy of Sciences (QYZDJSSW-DQC036).

Institutional Review Board Statement: Not applicable.

Informed Consent Statement: Not applicable.

Acknowledgments: Yonghong Shi and Juan Wang guided the authors in electronic microprobe analysis. We would like to thank Qiu-Li Li, Xiao-Xiao Ling, and Jiao Li for their assistance in SIMS $\mathrm{U}-\mathrm{Pb}$ dating of titanite at the Institute of Geology and Geophysics, Chinese Academy of Sciences, China. We would also like to thank Hong-Ying Zhou and Jia-Run Tu for their assistance in analyzing zirconium concentration in titanite at the Tianjin Institute of Geology and Mineral Resources, Chinese Academy of Geological Sciences, China. Zhen-Yu Chen helped the authors with electron microprobe trace element in rutile analysis at the Institute of Mineral Resources, Chinese Academy of Geological Sciences in Beijing, China. The quality of this manuscript was greatly improved through reviews by two anonymous referees.

Conflicts of Interest: The authors declare that they have no conflict of interest.

\section{References}

1. Chopin, C. Coesite and pure pyrope in high-grade blueschists of the Western Alps: A first record and some consequences. Contrib. Miner. Petrol. 1984, 86, 107-118. [CrossRef]

2. Smith, D.C. Coesite in clinopyroxene in the Caledonides and its implications for geodynamics. Nature 1984, 310, 641-644. [CrossRef]

3. Sobolev, N.V.; Shatsky, V.S. Diamond inclusions in garnets from metamorphic rocks: A new environment for diamond formation. Nature 1990, 343, 742-746. [CrossRef]

4. Xu, S.T.; Okay, A.I.; Ji, S.Y.; Sengör, A.M.C.; Su, W.; Liu, Y.C.; Jiang, L.L. Diamond from the Dabie Shan metamorphic rocks and its implication for tectonic setting. Science 1992, 256, 80-82.

5. Ye, K.; Cong, B.; Ye, D. The possible subduction of continental material to depths greater than $200 \mathrm{~km}$. Nature 2000, 407, 734-736. [CrossRef]

6. Liu, L.; Zhang, J.; Green, H.W.; Jin, Z.; Bozhilov, K.N. Evidence of former stishovite in metamorphosed sediments, implying subduction to $>350 \mathrm{~km}$. Earth. Planet. Sci. Lett. 2007, 263, 180-191. [CrossRef] 
7. Liu, L.; Zhang, J.F.; Cao, Y.T.; Green, H.W.; Yang, W.-Q.; Xu, H.-J.; Liao, X.-Y.; Kang, L. Evidence of former stishovite in UHP eclogite from the South Altyn Tagh, western China. Earth. Planet. Sci. Lett. 2018, 484, 353-362. [CrossRef]

8. Mei, H.L.; Yu, H.F.; Lu, S.N.; Li, H.M.; Li, Q.; Lin, Y.X.; Zuo, Y.C. Archean tonalite in the Dunhuang, Gansu Province: Age from the U-Pb single zircon and Nd isotope. Prog. Precambrian. Res. 1998, 21, 41-45. (In Chinese)

9. Zhang, J.; Gong, J.; Yu, S.C. 1.85 Ga HP granulite-facies metamorphism in the Dunhuang block of the Tarim Craton, NW China: Evidence from U-Pb zircon dating of mafic granulites. J. Geol. Soc. (Lond.) 2012, 169, 511-514. [CrossRef]

10. Zong, K.Q.; Zhang, Z.M.; He, Z.Y.; Hu, Z.C.; Santosh, M.; Liu, Y.S.; Wang, W. Early Palaeozoic high-pressure granulites from the Dunhuang block, northeastern Tarim Craton: Constraints on continental collision in the southern Central Asian Orogenic Belt. J. Metamorph. Geol. 2012, 30, 753-768. [CrossRef]

11. He, Z.; Zhang, Z.; Zong, K.; Xiang, H.; Klemd, R. Metamorphic P-T-t evolution of mafic HP granulites in the northeastern segment of the Tarim Craton (Dunhuang block): Evidence for early Paleozoic continental subduction. Lithos 2014, 196-197, 1-13. [CrossRef]

12. Peng, T.; Wang, H.; Chen, H.-X.; Meng, J.; Lu, J.-S.; Wang, G.-D.; Wu, C.-M. Preliminary report on the metamorphic evolution of the Guanyingou amphibolites, Dunhuang Metamorphic Complex, NW China. Acta Petrol. Sin. 2014, 30, 503-511. (In Chinese)

13. Zhao, Y.; Sun, Y.; Diwu, C.; Guo, A.-L.; Ao, W.-H.; Zhu, T. The Dunhuang block is a Paleozoic orogenic belt and part of the Central Asian Orogenic Belt (CAOB), NW China. Gondwana. Res. 2016, 30, 207-223. [CrossRef]

14. Wang, H.Y.C.; Chen, H.X.; Lu, J.S.; Wang, G.-D.; Peng, T.; Zhang, H.C.G.; Yan, Q.-R.; Hou, Q.-L.; Zhang, Q.; Wu, C.-M. Metamorphic evolution and SIMS U-Pb geochronology of the Qingshigou area, Dunhuang block, NW China: Tectonic implications of the southernmost Central Asian orogenic belt. Lithosphere 2016, 8, 463-479. [CrossRef]

15. Wang, H.Y.C.; Chen, H.X.; Zhang, Q.W.L.; Shi, M.-Y.; Yan, Q.-R.; Hou, Q.-L.; Zhang, Q.; Kusky, T.; Wu, C.-M. Tectonic mélange records the Silurian-Devonian subduction-metamorphic process of the southern Dunhuang terrane, southernmost Central Asian Orogenic Belt. Geology 2017, 45, 427-430. [CrossRef]

16. Wang, H.Y.C.; Wang, J.; Wang, G.-D.; Lu, J.-S.; Chen, H.-X.; Peng, T.; Zhang, H.C.G.; Zhang, Q.W.L.; Xiao, W.-J.; Hou, Q.-L.; et al. Metamorphic evolution and geochronology of the Dunhuang orogenic belt in the Hongliuxia area, northwestern China. J. Asian. Earth. Sci. 2017, 135, 51-69. [CrossRef]

17. Wang, H.Y.C.; Zhang, Q.W.L.; Chen, H.-X.; Liu, J.-H.; Zhang, H.C.G.; Pham, V.T.; Peng, T.; Wu, C.M. Paleozoic subduction of the southern Dunhuang Orogenic Belt, northwest China: Metamorphism and geochronology of the Shuixiakou area. Geodin. Acta 2018, 30, 63-83. [CrossRef]

18. Wang, H.Y.C.; Zhang, Q.W.L.; Lu, J.-S.; Chen, H.-X.; Liu, J.-H.; Zhang, H.C.G.; Pham, V.T.; Peng, T.; Wu, C.-M. Metamorphic evolution and geochronology of the tectonic mélange of the Dongbatu and Mogutai blocks, middle Dunhuang orogenic belt, northwestern China. Geosphere 2018, 14, 883-906. [CrossRef]

19. Zhang, Q.W.L.; Wang, H.Y.C.; Liu, J.-H.; Shi, M.-Y.; Chen, Y.-C.; Li, Z.M.G.; Wu, C.-M. Diverse subduction and exhumation of tectono-metamorphic slices in the Kalatashitage area, western Paleozoic Dunhuang Orogenic Belt, northwestern China. Lithos 2020, 360-361, 105434. [CrossRef]

20. Zhang, J.; Yu, S.; Mattinson, C.G. Early Paleozoic polyphase metamorphism in northern Tibet, China. Gondwana. Res. 2017, 41, 267-289. [CrossRef]

21. Lu, S.N.; Yu, H.F.; Li, H.K.; Guo, K.Y.; Wang, H.C.; Jin, W.; Zhang, C.L.; Liu, Y.S. Research on Precambrian Major Problems in Chinese; Geological Publishing House: Beijing, China, 2006. (In Chinese)

22. Cunningham, D.; Zhang, J.; Li, Y. Late Cenozoic transpressional mountain building directly north of the Altyn Tagh Fault in the Sanweishan and Nanjieshan, North Tibetan Foreland, China. Tectonophysics 2016, 687, 111-128. [CrossRef]

23. Festa, A.; Dilek, Y.; Pini, G.A.; Codegone, G.; Ogata, K. Mechanisms and processes of stratal disruption and mixing in the development of mélanges and broken formations: Redefining and classifying mélanges. Tectonophysics 2012, 568-569, 7-24. [CrossRef]

24. Whitney, D.L.; Evans, B.W. Abbreviations for names of rock-forming minerals. Am. Miner. 2010, 95, 185-187. [CrossRef]

25. Hwang, S.L.; Shen, P.; Chu, H.T.; Yui, T.F.; Iizuka, Y.; Schertl, H.P. Rutile inclusions in garnet from a dissolution-reprecipitation mechanism. J. Metamorph. Geol. 2019, 37, 1079-1098. [CrossRef]

26. Ague, J.J.; Eckert, J.O. Precipitation of rutile and ilmenite needles in garnet: Implications for extreme metamorphic conditions in the Acadian Orogen, U.S.A. Am. Miner. 2012, 97, 840-855. [CrossRef]

27. Droop, G.T.R. A general equation for estimating $\mathrm{Fe}^{3+}$ concentrations in ferromagnesian silicates and oxides from microprobe analyses, using stoichiometric criteria. Miner. Mag. 1987, 51, 431-435. [CrossRef]

28. Holland, T.; Blundy, J. Non-ideal interactions in calcic amphiboles and their bearing on amphibole-plagioclase thermometry. Contrib. Miner. Petrol. 1994, 116, 433-447. [CrossRef]

29. Chen, Z.Y.; Li, Q.L. Zr-in-rutile thermometry in eclogite at Jinheqiao in the Dabie orogen and its geochemical implications, Chinese. Chin. Sci. Bull. 2008, 53, 768-776. [CrossRef]

30. Li, Q.L.; Li, X.H.; Liu, Y.; Wu, F.-Y.; Yang, J.-H.; Mitchell, R.H. Precise U-Pb and Th-Pb age determination of kimberlitic perovskites by secondary ion mass spectrometry. Chem. Geol. 2010, 269, 396-405. [CrossRef]

31. Li, Y.; Zhou, H.-W.; Li, Q.-L.; Xiang, H.; Zhong, Z.-Q.; Brouwer, F.M. Palaeozoic polymetamorphism in the North Qinling orogenic belt, Central China: Insights from petrology and in situ titanite and zircon U-Pb geochronology. J. Asian. Earth. Sci. 2014, 92, 77-91. [CrossRef] 
32. Ling, X.X.; Schmädicke, E.; Li, Q.L.; Gose, J.; Wu, R.-H.; Wang, S.-Q.; Liu, Y.; Tang, G.-Q.; Li, X.-H. Age determination of nephrite by in-situ SIMS U-Pb dating syngenetic titanite: A case study of the nephrite deposit from Luanchuan, Henan, China. Lithos 2015, 220-223, 289-299. [CrossRef]

33. Li, Q.L.; Zhao, L.; Zhang, Y.B.; Yang, J.H.; Kim, J.N.; Han, R.H. Zircon-titanite-rutile U-Pb system from metamorphic rocks of Jungshan "Group" in Korea: Implications of tectono-thermal events from Paleoproterozoic to Mesozoic. Acta Petrol. Sin. 2016, 32, 3019-3032. (In Chinese)

34. Aleinikoff, J.N.; Wintsch, R.P.; Tollo, R.P.; Unruh, D.M.; Fanning, C.M.; Schmitz, M.D. Ages and origins of rocks of the Killingworth dome, south-central Connecticut: Implications for the tectonic evolution of southern New England. Am. J. Sci. 2007, 307, 63-118. [CrossRef]

35. Tera, F.; Wasserburg, G.J. U-Th-Pb systematics in three Apollo 14 basalts and the problem of initial Pb in lunar rocks. Earth. Planet. Sci. Lett. 1972, 14, 281-304. [CrossRef]

36. Ludwig, K.R. Users Manual for Isoplot/Ex Rev. 2.49; Special Publication No. 1a; Berkeley Geochronology Centre: Berkeley, CA, USA, 2001.

37. Nakamura, D. A new formulation of garnet-clinopyroxene geothermometer based on accumulation and statistical analysis of a large experimental data set. J. Metamorph. Geol. 2009, 27, 495-508. [CrossRef]

38. Beyer, C.; Frost, D.J.; Miyajima, N. Experimental calibration of a garnet-clinopyroxene geobarometer for mantle eclogites. Contrib. Miner. Petrol. 2015, 169, 1-21. [CrossRef]

39. Gerya, T.V.; Perchuk, L.L.; Triboulet, C.; Audren, C.; Sez'ko, A.I. Petrology of the Tumanshet zonal metamorphic complex, eastern Sayan. Petrology 1997, 5, 503-533.

40. Hayden, L.A.; Watson, E.B.; Wark, D.A. A thermobarometer for sphene (titanite). Contrib. Miner. Petrol. 2008, 155, 529-540. [CrossRef]

41. Ferry, J.M.; Watson, E.B. New thermodynamic models and revised calibrations for the Ti-in-zircon and Zr-in-rutile thermometers. Contrib. Miner. Petrol. 2007, 154, 429-437. [CrossRef]

42. Jiao, S.; Guo, J.; Mao, Q.; Zhao, R. Application of Zr-in-rutile thermometry: A case study from ultrahigh-temperature granulites of the Khondalite belt, North China Craton. Contrib. Miner. Petrol. 2011, 162, 379-393. [CrossRef]

43. Watson, E.B.; Wark, D.A.; Thomas, J.B. Crystallization thermometers for zircon and rutile. Contrib. Miner. Petrol. 2006, 151, 413-433. [CrossRef]

44. Tomkins, H.S.; Powell, R.; Ellis, D.J. The pressure dependence of the zirconium-in-rutile thermometer. J. Metamorph. Geol. 2007, 25, 703-713. [CrossRef]

45. Zack, T.; Moraes, R.; Kronz, A. Temperature dependence of Zr in rutile: Empirical calibration of a rutile thermometer. Contrib. Miner. Petrol. 2004, 148, 471-488. [CrossRef]

46. Spear, F.S.; Florence, F.P. Thermobarometry in granulites: Pitfalls and new approaches. Precambrian Res. 1992, 55, $209-241$. [CrossRef]

47. Morimoto, N. Nomenclature of Pyroxenes. Miner. Petrol. 1988, 39, 55-76. [CrossRef]

48. Smith, D.C. The pressure and temperature dependence of Al-solubility in sphene in the system Ti-Al-Ca-Si-O-F. Prog. Exp. Petrol. (Ser. D) 1981, 18, 193-197.

49. Franz, G.; Spear, F.S. Aluminous titanite (sphene) from the eclogite-zone, south-central Tauern Window, Austria. Chem. Geol. 1985, 50, 33-46. [CrossRef]

50. Castelli, D. Eclogitic metamorphism in carbonate rocks: The example of impure marbles from the Sesia-Lanzo Zone, Italian Western Alps. J. Metamorph. Geol. 1991, 9, 61-77. [CrossRef]

51. Carswell, D.A.; Wilson, R.N.; Zhai, M. Ultra-high pressure aluminous titanites in carbonate-bearing eclogites at Shuanghe in Dabieshan, central China. Miner. Mag. 1996, 60, 461-471. [CrossRef]

52. O'Brien, P.J.; Rötzler, J. High-pressure granulites: Formation, recovery of peak conditions and implications for tectonics. J. Metamorph. Geol. 2003, 21, 3-20. [CrossRef]

53. Winter, J.D. Principles of Igneous and Metamorphic Petrology, 2nd ed.; Pearson Education: Upper Saddle River, NJ, USA, 2014.

54. Kennedy, C.S.; Kennedy, G.C. The equilibrium boundary between graphite and diamond. J. Geophys. Res. 1976, 81, 2467-2470. [CrossRef]

55. Bose, K.; Ganguly, J. Quartz-coesite transition revisited: Reversed experimental determination at 500-1200 ${ }^{\circ} \mathrm{C}$ and retrieved thermochemical properties. Am. Miner. 1995, 80, 231-238. [CrossRef]

56. Ye, K.; Ye, D. Significance of phosphorous (P)- and magnesium (Mg)-bearing high-Al titanite in high-pressure marble from Yangguantun, Rongcheng County, Shandong Province. Chin. Sci. Bull. 1996, 41, 1194-1197.

57. Tropper, P.; Manning, C.E.; Essene, E.J. The substitution of Al and F in titanite at high pressure and temperature: Experimental constraints on phase relations and solid solution properties. J. Petrol. 2002, 43, 1787-1814. [CrossRef]

58. Enami, M.; Suzuki, K.; Liou, J.G.; Bird, D.K. Al-Fe $\mathrm{F}^{3+}$ and F-OH substitutions in titanite and constrains on their P-T dependence. Eur. J. Miner. 1993, 5, 219-231. [CrossRef]

59. Castelli, D.; Rubatto, D. Stability of Al- and F-rich titanite in metacarbonate: Petrologic and isotopic constraints from a polymetamorphic eclogitic marble of the internal Sesia Zone (Western Alps). Contrib. Miner. Petrol. 2002, 142, 627-639. [CrossRef] 
60. Ryan-Davis, J.; Lackey, J.S.; Gevedon, M.; Barnes, J.D.; Lee, C. -T.A.; Kitajima, K.; Valley, J.W. Andradite skarn garnet records of exceptionally low $\delta 18 \mathrm{O}$ values within an Early Cretaceous hydrothermal system, Sierra Nevada, CA. Contrib. Miner. Petrol. 2019, 174, 68. [CrossRef]

61. Alaminia, Z.; Mehrabi, B.; Razavi, S.M.H.; Tecce, F. Mineral chemistry, petrogenesis and evolution of the Ghorveh-Seranjic skarn, Northern Sanandaj Sirjan Zone, Iran. Miner. Petrol. 2020, 114, 15-38. [CrossRef]

62. Pearce, J.A. A user's guide to basalt discrimination diagrams. In Trace Element Geochemistry of Volcanic Rocks: Applications for Massive Sulphide Exploration; Wyman, D.A., Ed.; Short Course Notes 12; Geological Association of Canada: Newfoundland, NL, Canada, 1996; pp. 79-113.

63. Pearce, J.A. Trace element characteristics of lavas from destructive plate boundaries. In Andesites; Thorpe, R.S., Ed.; Wiley: Chichester, UK, 1982; pp. 525-548.

64. Sun, S.S.; McDonough, W.F. Chemical and isotopic systematics of oceanic basalts: Implications for mantle composition and processes. Geol. Soc. Lond. Spec. Publ. 1989, 42, 313-345. [CrossRef]

65. Chen, Y.; Wei, C.; Zhang, J.; Chu, H. Metamorphism and zircon U-Pb dating of garnet amphibolite in the Baoyintu Group, Inner Mongolia. Sci. Bull. 2015, 60, 1698-1707. [CrossRef]

66. Wu, J.; Zhai, M.; Zhang, H.; Guo, J.; Wang, H.; Yang, W.; Zhang, H.; Hu, B. Petrologic indicators of prograde metamorphism in Paleoproterozoic garnet mafic granulites from the Huai'an complex, North China Craton. Sci. Bull. 2018, 63, 81-84. [CrossRef]

67. Frost, B.R.; Chamberlain, K.R.; Schumacher, J.C. Sphene (titanite): Phase relations and role as a geochronometer. Chem. Geol. 2001, 172, 131-148. [CrossRef]

68. Oberti, R.; Smith, D.C.; Rossi, G.; Caucia, F. The crystal chemistry of high-aluminum titanites. Eur. J. Miner. 1991, 3, 777-792. [CrossRef]

69. Snoeyenbos, D.R.; Williams, M.L.; Hanmer, S. Archean high-pressure metamorphism in the western Canadian Shield. Eur. J. Miner. 1995, 7, 1251-1272. [CrossRef]

70. Smith, D.C. Highly aluminous sphene (titanite) in natural high-pressure hydrous-eclogite-facies rocks from Norway and Italy, and in experimental runs at high pressure. In Proceedings of the 26th International Geological Congress, Paris, France, 7-17 July 1980.

71. Smith, D.C. A review of the peculiar mineralogy of the "Norwegian coesite eclogite province", with crystal-chemical, petrological, geochemical and geodynamical notes and an extensive bibliography. In Developments and Petrology 12, Eclogite-facies Rocks; Smith, D.C., Ed.; Elsevier: Amsterdam, The Netherlands, 1988.

72. Brey, G.P.; Nickel, K.G.; Kogarko, L. Garnet-pyroxene equilibria in the system CaO-MgO-Al2O3-SiO2 (CMAS): Prospects for simplified ('T-independent') lherzolite barometry and an eclogite-barometer. Contrib. Miner. Petrol. 1986, 92, 448-455. [CrossRef]

73. Mukhopadhyay, B. Garnet-clinopyroxene geobarometry: The problems, a prospect, and an approximate solution with some applications. Am. Miner. 1991, 76, 512-529.

74. Simakov, S.K.; Taylor, L.A. Geobarometry for mantle eclogites: Solubility of Ca-tschermaks in clinopyroxene. Int. Geol. Rev. 2000, 4, 534-544. [CrossRef]

75. Simakov, S.K. Garnet-clinopyroxene and clinopyroxene geothermobarometry of deep mantle and crust eclogites and peridotites. Lithos 2008, 106, 125-136. [CrossRef]

76. Mercier, J.-C.C. Single-pyroxene thermobarometry. Tectonophysics 1980, 70, 1-37. [CrossRef]

77. Taylor, W.R.; Nimis, P. A single-pyroxene thermobarometer for lherzolitic Cr-diopside and its application in diamond exploration. In Proceedings of the Seventh International Kimberlite Conference, Cape Town, South Africa, 13-17 April 1998; pp. 897-898.

78. Nimis, P.; Taylor, W.R. Single clinopyroxene thermobarometry for garnet peridotites. Part, I. Calibration and testing of a Cr-in-Cpx barometer and an enstatite-in-Cpx thermometer. Contrib. Miner. Petrol. 2000, 139, 541-554. [CrossRef]

79. Holder, R.M.; Hacker, B.R. Fluid-driven resetting of titanite following ultrahigh-temperature metamorphism in southern Madagascar. Chem. Geol. 2019, 504, 38-52. [CrossRef]

80. Scott, D.J.; St-Onge, M.R. Constraints on Pb closure temperature in titanite based on rocks from the Ungava orogen, Canada: Implications for U-Pb geochronology and P-T-t path determinations. Geology 1995, 23, 1123-1126. [CrossRef]

81. Sun, J.; Yang, J.; Wu, F.; Xie, L.; Yang, Y.; Liu, Z.; Li, X. In situ U-Pb dating of titanite by LA-ICPMS. Chin. Sci. Bull. 2012, 57, 2506-2516. [CrossRef]

82. Walters, J.B.; Kohn, M.J. Protracted thrusting followed by late rapid cooling of the Greater Himalayan Sequence, Annapurna Himalaya, central Nepal: Insights from titanite petrochronology. J. Metamorph. Geol. 2017, 35, 897-917. [CrossRef]

83. Ernst, W.G. Tectonic history of subduction zones inferred from retrograde blueschist P-T paths. Geology 1988, 16, 1081-1084. [CrossRef] 